\title{
SAND98-2353 J
}

Contribution from The Department of Chemistry and Biochemistry:

University of Notre Dame. Notre Dame. Indiana 46.556.

Naterials Theory and Computation Department. Sandia National Laboratories.

Albuquerque, New Mexico 8 i18.5-1340.

The Department of Chemistry. Unirersity of New Mexico. Albuquerque. New Mexico $5 i 131$. and The Department of Physics. Knox College, Galesburg. Illinois 61401

Conformational Diversity in (Octaethylporphinato)(trichloroacetato)iron(III) Derivatives

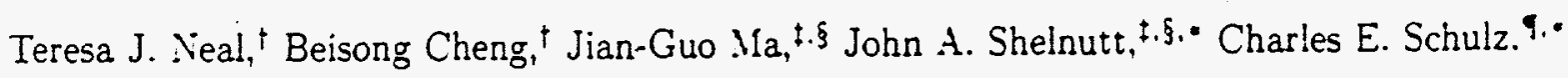
and W. Robert Scheidt t.*

September 8, 1998

\footnotetext{
The University of Notre Dame

t The Cniversity of Niew Hexico

SMaterials Theory and Computation Department

TKnox College

- To whom correspondence should be addressed
} 


\section{DISCLAIMER}

This report was prepared as an account of work sponsored by an agency of the United States Government. Neither the United States Government nor any agency thereof, nor any of their employees, make any warranty, express or implied, or assumes any legal liability or responsibility for the accuracy, completeness, or usefulness of any information, apparatus, product, or process disclosed, or represents that its use would not infringe privately owned rights. Reference herein to any specific commercial product, process, or service by trade name, trademark, manufacturer, or otherwise does not necessarily constitute or imply its endorsement, recommendation, or favoring by the United States Government or any agency thereof. The views and opinions of authors expressed herein do not necessarily state or reflect those of the United States Government or any agency thereof. 


\section{DISCLAIMER}

Portions of this document may be illegible in electronic image products. Images are produced from the best available original document. 
Abstract: Treatment of $[\mathrm{Fe}(\mathrm{OEP})]_{2} \mathrm{O}$ with trichloroacetic acid (2.5-fold excess) results in the formation of (octaethylporphinato)(trichloroacetato)iron(III). Various crystalline solvates can be isolated, depending on the crystallization solvent. Initial crystallization with $\mathrm{CHCl}_{3}$ /hexanes resulted in the isolation of an unsolvated form. $\left.\mathrm{Fe}(\mathrm{OEP})\left(\mathrm{O}_{2} \mathrm{C}_{2} \mathrm{Cl}_{3}\right)\right]$. This form contains wo distinct porphyrin core conformations at the same lattice site: one is domed and the other is - ruffed. Crystal data for $\left[\mathrm{Fe}(\mathrm{OEP})\left(\mathrm{O}_{2} \mathrm{C} \cdot \mathrm{Cl}_{3}\right)\right]: a=14.7-34(4)$ A. $b=13.674(1)$ A. $c=17.5+1,51$ A. $3=90.67(1)^{\circ} . V=3545.8(14) A^{3}$. monoclinic. space group $P 2_{1} / n . Z=4$. Subsequent crystallizations with $\mathrm{CHCl}_{3} /$ hexanes resulted in a new crystalline form, $\left[\mathrm{Fe}(\mathrm{OEP})\left(\mathrm{O}_{2} \mathrm{C}_{2} \mathrm{Cl}_{3}\right) ! \cdot\right.$. $\mathrm{CHCl}_{3}$; the porphyrin core is slightly ruffed. Crystal data for $\left[\mathrm{Fe}(\mathrm{OEP})\left(\mathrm{O}_{2} \mathrm{C}_{2} \mathrm{Cl}_{3}\right)\right] \cdot \mathrm{CHCl}_{3}: a=$ $12.323(1)$ A. $b=13.062(3)$ A. $c=14.327(2)$ A. $\alpha=89.32(1)^{\circ}, 3=113.36(2)^{\circ} . \gamma=105.26(1)^{\circ}$. $V=2031.3(6) \AA^{3}$, triclinic. space group $P \bar{l} . Z=2$. Crystallization with $\mathrm{CH}_{2} \mathrm{Cl}_{2}$ /hexanes resulted in the isolation of yet another form, $\left.\mathrm{Fe}(\mathrm{OEP})\left(\mathrm{O}_{2} \mathrm{C}_{2} \mathrm{Cl}_{3}\right)\right] \cdot \mathrm{HO}_{2} \mathrm{C}_{2} \mathrm{Cl}_{3}$. which contains two independent molecules in the unit cell: molecule $A$ is slightly saddled and molecule $B$ is modestly ruffled. Crystal data for $\left[\mathrm{Fe}(\mathrm{OEP})\left(\mathrm{O}_{2} \mathrm{C}_{2} \mathrm{Cl}_{3}\right)\right] \cdot \mathrm{HO}_{2} \mathrm{C}_{2} \mathrm{Cl}_{3}: a=13.148(3) .1, b=13.45 .5(3)$ $A, c=23.761(5) A, \alpha=90.72(3)^{\circ}, 3=91.24(3)^{\circ}, \gamma=92.36(3)^{\circ}, V=4198.5(15) A^{3}$, triclinic. space group $P \overrightarrow{1}, Z=4$. All conformations form $\pi-\pi$ dimers in the solid state. Temperaturedependent magnetic susceptibility measurements showed that $\left[\mathrm{Fe}(\mathrm{OEP})\left(\mathrm{O}_{2} \mathrm{C}_{2} \mathrm{Cl}_{3}\right)\right] \cdot \mathrm{CHCl}_{3}$ contains a high-spin iron(III) center; the data for [ $\left.\mathrm{Fe}(\mathrm{OEP})\left(\mathrm{O}_{2} \mathrm{C}_{2} \mathrm{Cl}_{3}\right)\right] \cdot \mathrm{HO}_{2} \mathrm{C}_{2} \mathrm{Cl}_{3}$ are understood in terms of an admixed intermediate-spin state $(S=3 / 2,5 / 2)$ and are readily fit to a Maltempo model with a ground state multiplet containing about $78 \% \mathrm{~S}=5 / 2$ character and $22 \%$ $\mathrm{S}=3 / 2$ character. The structural data for $\left[\mathrm{Fe}(\mathrm{OEP})\left(\mathrm{O}_{2} \mathrm{C}_{2} \mathrm{Cl}_{3}\right)\right] \cdot \mathrm{CHCl}_{3}$ are consistent with the observed high-spin state, while data for $\left[\mathrm{Fe}(\mathrm{OEP})\left(\mathrm{O}_{2} \mathrm{C}_{2} \mathrm{Cl}_{3}\right)\right] \cdot \mathrm{HO}_{2} \mathrm{C}_{2} \mathrm{Cl}_{3}$ are consistent with the admixed-spin iron(III) character. The ubserved core conformations have been described by a normal-coordinate structural decomposition method.

Keywords: iron porphyrins; macrocyclic conformation; porphyrin structure; X-ray crystallography; normal-coordinate structural decomposition method 


\section{Introduction}

Porphyrin ring distortions have attracted attention because of the recent observation that classes of hemoprotein derivatives contain similarly conformationally distorted macrocycles $\vdots 1:$. For example. the conformation of the heme group of each of the more than 25 peroxidases and their mutants is predominantly saddled. while the heme groups of cytochrome $c$ tend to be ruffled. Although an absolute correlation between conformational distortion and protein function has not yet been made, distortion of the heme macrocycle may influence chemical and photochemical properties of porphyrins [2].

The conformation of the macrocycle can be influenced by several factors including peripheral substituents [3-5], central metal ion [6.7]. or by the environment of the heme [7]. Steric crowding at the periphery generally leads to substantial nonplanarity of the core. and it has recently been shown that the magnitude of ring deformation increases with increasing steric bulk at the periphery [5]. Correlations between the central metal ion and the magnitude of core deformation have been established for a series of nonplanar meso-substituted octaethylporphinato derivatives [6]. The results for a series of metal complexes of octaethyltetraphenylporphyin clearly show that the size of the metal atom is related to the magnitude of planarity of the macrocycle. with a smaller metal atom favoring a more nonplanar conformation. It has been previously predicted that with a central metal ion as large as iron the macrocycle is not likely to exhibit nonplanar structures in the absence of large $\left(>10 \mathrm{~kJ} \cdot \mathrm{mol}^{-1}\right)$ external influences on the structure $[\vec{i}]$. Finally, the environment around the heme may be the cause of significant solid-state macrocyclic distortions. Protein structures have revealed a large number of distorted hemes which. when put in solution, are nearly planar [7]. Thus. in the solid state, external forces can cause significant distortions.

Jentzen and Shelnutt have recently developed a structural analysis method [8] for classifying and quantifying heme distortions. This method is based on the observation that the out-of-plane distortions are comparable to displacements along the lowest-frequency out-ofplane normal coordinates of the macrocycle. In its simplest form, the normal-coordinate struc- 
tural decomposition (NSD) method uses a linear combination of only the six lowest-frequency out-of-plane normal coordinates of the macrocycle. one of each $D_{i h}$ out-of-plane symmetry ty.pe. to simulate the macrocyclic distortion. In most cases. macrocyclic distortions can be described adequately by summing displacements along these six out-of-plane normal coordinates denoted sad. ruf. dom, wav( $(x)$. uav (y). and pro. Pure displacements along these coordinates are commonly observed symmetric deformations seen in X-ray crystal structures of symmetrically. substituted porphyrins. The amounts of saddling (sad). ruffing (ruf). doming (dom). waving $[w a v(\tau)$ and $u a v(y)]$, and propellering (pro) deformations required to simulate more complicated out-of-plane distortions of porphyrin macrocycles are determined by the NSD procedure. The normal-coordinate structural decomposition method has been used to classify and quantify the distortions of more than 100 synthetic and 800 protein-bound metalloporphyrin derivatives defined by X-ray crystal structures. Moreover, it has revealed information that was previously disguised in the complicated heme distortions caused by the asymmetric heme environment.

In the past decade, much research has focused on the synthesis of mimics of distorted porphyrins found in heme proteins. The synthetic analogs that show significant distortion of the macrocycle are typically mesa-substituted or mesa-substituted octaethylporphinato derivatives, since bulky groups in the meso positions tend to favor ring distortion. However, mesosubstituted derivatives are rarely found in biological systems, and heme proteins can be better modeled by the use of octaethylporphinato derivatives. In this paper, we describe the synthesis and structural and physical characterization of three crystalline forms of a five-coordinate iron octaethylporphinato derivative. Although peripheral substitution, central metal ion, and axial ligation are identical in all forms. the porphỵrin core deformations are different. Most interestingly, one crystalline form displays two distinct core conformations at the same lattice site. The structure determinations show that although octaethylporphinato derivatives are not sterically encumbering, they are still capable of adopting various core conformations, and that subtle external solid-state forces can force the porphyrin core to change among conformations. Physical characterization includes magnetic susceptibility measurements and crystal structure 
determinations. Further, a normal-coordinate structural decomposition method has been used to analyze and quantify the observed core conformations.

\section{Experimental}

\subsection{General Information.}

Hexanes, $\mathrm{CHCl}_{3}$, and $\mathrm{CH}_{2} \mathrm{Cl}_{2}$ were purchased from $\mathrm{Fisher,} \mathrm{trichloroacetic} \mathrm{acid} \mathrm{from} \mathrm{Aldrich.}$ and $\mathrm{H}_{2} \mathrm{OEP}$ [9] from Midcentury Chemicals. Hexanes was distilled from sodium/benzophenone. and $\mathrm{CHCl}_{3}$ and $\mathrm{CH}_{2} \mathrm{Cl}_{2}$ were distilled from $\mathrm{CaH}_{2}$. Iron was inserted into $\mathrm{H}_{2} \mathrm{OEP}$ by standard methods [10]. $[\mathrm{Fe}(\mathrm{OEP})]_{2} \mathrm{O}$ was prepared by washing $[\mathrm{Fe}(\mathrm{OEP})(\mathrm{Cl})]$ in $\mathrm{CH}_{2} \mathrm{Cl}_{2}$ with $2 \mathrm{MI} \mathrm{hOH}$. UV-vis spectra were recorded on a Perkin-Elmer Lambda 6 spectrometer.

\subsection{Synthesis and Crystallization of $\left[\mathrm{Fe}(\mathrm{OEP})\left(\mathrm{O}_{2} \mathrm{C}_{2} \mathrm{Cl}_{3}\right)\right]$ Complexes.}

Unsolvated $\left[\mathrm{Fe}(\mathrm{OEP})\left(\mathrm{O}_{2} \mathrm{C}_{2} \mathrm{Cl}_{3}\right)\right]$ was obtained by stirring a solution of $[\mathrm{Fe}(\mathrm{OEP})]_{2} \mathrm{O}$ and trichloroacetic acid (2.5-fold excess) in $\mathrm{CHCl}_{3}$ before being transferred into $16 \times 1.50 \mathrm{~mm}$ test tubes and layered with hexanes. Several subsequent attempts to obtain crystals of this compound resulted in the isolation of a solvated crystalline form, $\left[\mathrm{Fe}(\mathrm{OEP})\left(\mathrm{O}_{2} \mathrm{C}_{2} \mathrm{Cl}_{3}\right)\right] \cdot \mathrm{CHCl}_{3}$. $\left[\mathrm{Fe}(\mathrm{OEP})\left(\mathrm{O}_{2} \mathrm{C}_{2} \mathrm{Cl}_{3}\right)\right] \cdot \mathrm{HO}_{2} \mathrm{C}_{2} \mathrm{Cl}_{3}$ was obtained when $\mathrm{CH}_{2} \mathrm{Cl}_{2}$ replaced $\mathrm{CHCl}_{3}$ as the reaction solvent. Dark purple crystals formed after about one week for all complexes; $\mathrm{VV} / \mathrm{vis}\left(\mathrm{CH}_{2} \mathrm{Cl}_{2}\right)$ $\lambda_{\max } 378$ (Soret), 504, 534, $638 \mathrm{~nm}$.

\subsection{Structure Determinations.}

$A$ crystal of $\left[\mathrm{Fe}(\mathrm{OEP})\left(\mathrm{O}_{2} \mathrm{C}_{2} \mathrm{Cl}_{3}\right)\right]$ was examined on an Enraf-Nonius CAD4 diffractometer. Precise cell constants were determined from least-squares refinement of 25 automatically centered reflections. Four standard reflections were monitored during data collection for crystal movements and possible crystal deterioration. No significant decay was observed. Intensity data were reduced by using the data reduction program suite of $R$. H. Blessing [11]. X-ray diffraction data for the two solvated crystalline forms were collected on an Enraf-Nonius FAST 
area detector diffractometer as described previously [12].

All structures were solved by direct methods with the SHELXS- $x 6$ program and were refined against $\mathrm{F}^{2}$ with the SHELXL program [13]. Surprisingly: the porphyrin ligand in [Fe(OEP)$\left(\mathrm{O}_{2} \mathrm{C}_{2} \mathrm{Cl}_{3}\right)$, appeared to have a significant amount of disorder. Several adjacent atoms of the core (and two ethyl groups) appeared to have two distinct locations. with effectively equal atomic populations. In the disorder model used. these core atoms were separated by 0.55 to 0.69 A. All ordered, non-hydrogen atoms were refined. anisotropically: the several disordered atoms were refined with isotropic temperature factors. In the $\left[\mathrm{Fe}(\mathrm{OEP})\left(\mathrm{O}_{2} \mathrm{C}_{2} \mathrm{Cl}_{3}\right)\right] \cdot \mathrm{CHCl}_{3}$ structure, there was no disorder except for a minor one of the trichloromethyl group of the axial ligand (two orientations, occupancy factors 0.925 and 0.075 ). $\left[\mathrm{Fe}(\mathrm{OEP})\left(\mathrm{O}_{2} \mathrm{C}_{2} \mathrm{Cl}_{3}\right)\right] \cdot \mathrm{HO}_{2} \mathrm{C}_{2} \mathrm{Cl}_{3}$ crystallized in a primitive unit cell with four molecules per unit cell and no apparent symmetry. The centrosymmetric space group $P \bar{I}$ was chosen as the most probable space group. This requires that there are two independent molecules per asymmetric unit (molecule $A$ and molecule B). The consideration of possible higher symmetry, including use of MISSYM [1 4 ]. did not reveal an alternate choice of space group. Disorder of the trichloromethyl group (two orientations, occupancy factors 0.614 and 0.386 ) of the axial ligand was also found in molecule $A$ of $\left[\mathrm{Fe}(\mathrm{OEP})\left(\mathrm{O}_{2} \mathrm{C}_{2} \mathrm{Cl}_{3}\right)\right] \cdot \mathrm{HO}_{2} \mathrm{C}_{2} \mathrm{Cl}_{3}$. An ethyl group of molecule $\mathrm{B}$ of $\left[\mathrm{Fe}(\mathrm{OEP})\left(\mathrm{O}_{2} \mathrm{C}_{2} \mathrm{Cl}_{3}\right)\right] \cdot-$ $\mathrm{HO}_{2} \mathrm{C}_{2} \mathrm{Cl}_{3}$ is disordered over two orientations (occupancy factors 0.695 and 0.305 ). For both solvated structures, all non-hydrogen atoms, except those disordered atoms of smallest occupancy, were refined anisotropically. An absorption correction was applied at the final stages of the structure determination of $\left[\mathrm{Fe}(\mathrm{OEP})\left(\mathrm{O}_{2} \mathrm{C}_{2} \mathrm{Cl} 3\right)\right]$ and $\left[\mathrm{Fe}(\mathrm{OEP})\left(\mathrm{O}_{2} \mathrm{C}_{2} \mathrm{Cl}_{3}\right)\right] \cdot \mathrm{HO}_{2} \mathrm{C}_{2} \mathrm{Cl}_{3}$. Hydrogen atoms were included into all models as fixed. idealized contributors.

Crystal data, data collection parameters, and refinement information for all structures are given in Table 1. Final atomic coordinates for the three structures are listed in Table 2.

\subsection{Physical Characterization.}

Magnetic susceptibility measurements were obtained on ground samples in the solid state 
over the temperature range $6-300 \mathrm{~K}$ on a Quantum Design MPMS SQLID susceptometer. Identical measurements at two fields $(2$ and $20 \mathrm{kG})$ showed that no ferromagnetic impurities were present. $\chi_{\mathrm{MI}}$ was corrected for the underlying porphyrin ligand diamagnetism according to previous experimentally observed values [15]: all remaining diamagnetic contributions ( d $_{13}$ ) were calculated using Pascal's constants [16.17]. All measurements included a correction for the diamagnetic sample holder.

Resonance Raman studies for crystals of $\left[\mathrm{Fe}(\mathrm{OEP})\left(\mathrm{O}_{2} \mathrm{C}_{2} \mathrm{Cl}_{3}\right)\right] \cdot \mathrm{HO}_{2} \mathrm{C}_{2} \mathrm{Cl}_{3}$ were carried out at room temperature with $406.7 \mathrm{~nm}$ excitation [provided by a Krypton ion laser (Coherent. IN:VOVA 20)]. However, the crystals are unstable in the laser beam even at less than $10 \mathrm{~mW}$ of laser power. most of which is defected at grazing angle. The Raman lines disappear after about one hour in the beam; consequently the spectra are not of good quality.

\section{Results}

$\left[\mathrm{Fe}(\mathrm{OEP})\left(\mathrm{O}_{2} \mathrm{C}_{2} \mathrm{Cl}_{3}\right)\right]$ has been found to crystallize as various forms, depending on the crystallization solvent. Initial isolation of $\left[\mathrm{Fe}(\mathrm{OEP})\left(\mathrm{O}_{2} \mathrm{C}_{2} \mathrm{Cl}_{3}\right)\right]$ from $\mathrm{CHCl}_{3} /$ hexanes revealed an unsolvated complex which contained disorder over several adjacent atoms of the porphyrin core. Figure la illustrates a disorder model and shows the labeling scheme for all atoms of $[\mathrm{Fe}(\mathrm{OEP})$ $\left.\left(\mathrm{O}_{2} \mathrm{C}_{2} \mathrm{Cl}_{3}\right)\right]$. In this disorder model there are two very different porphyrin core conformations with nearly equivalent populations (51:49). Conformation A (the core containing only the solid bonds in Figure 1a) is slightly domed, while conformation B (the core containing the outlined bonds in Figure $1 \mathrm{a}$ ) is modestly $\mathrm{S}_{4}$-ruffled. Figures $2 \mathrm{a}$ and $2 \mathrm{~b}$ are formal diagrams of the porphinato cores of $\left[\mathrm{Fe}(\mathrm{OEP})\left(\mathrm{O}_{2} \mathrm{C}_{2} \mathrm{Cl}_{3}\right)\right]$. conformation $\mathrm{A}$, and $\left[\mathrm{Fe}(\mathrm{OEP})\left(\mathrm{O}_{2} \mathrm{C}_{2} \mathrm{Cl}_{3}\right)\right]$, conformation B. respectively.

Repeated subsequent attempts at crystallizing the unsolvated complex $\left[\mathrm{Fe}(\mathrm{OEP})\left(\mathrm{O}_{2} \mathrm{C}_{2} \mathrm{Cl}_{3}\right)\right]$ using the same solvent system ( $\mathrm{CHCl}_{3} /$ hexanes) resulted in the isolation of a solvated form, $\left[\mathrm{Fe}(\mathrm{OEP})\left(\mathrm{O}_{2} \mathrm{C}_{2} \mathrm{Cl}_{3}\right)\right] \cdot \mathrm{CHCl}_{3}$. An ORTEP view is shown in Figure $1 \mathrm{~b}$, which illustrates the labeling scheme for all atoms. The core conformation for $\left[\mathrm{Fe}(\mathrm{OEP})\left(\mathrm{O}_{2} \mathrm{C}_{2} \mathrm{Cl}_{3}\right) \cdot \mathrm{CHCl}_{3}\right.$ is slightly 
ruffled. as seen in the formal diagram of the porphinato core (Figure 2c).

Attempts at crystallizing the unsolvated complex using $\mathrm{CH}_{2} \mathrm{Cl}_{2}$ / hexanes resulted in the isolation of a third form. [ $\left.\mathrm{Fe}(\mathrm{OEP})\left(\mathrm{O}_{2} \mathrm{C}_{2} \mathrm{Cl}_{3}\right)\right] \cdot \mathrm{HO}_{2} \mathrm{C}_{2} \mathrm{Cl}_{3}$. The solid-state structure revealed two independent porphyrin rings (molecules $A$ and $B$ ). which are illustrated in Figures $1 \mathrm{c}$ and 1d. The core conformations of the two independent rings are strikingly different. As can be seen in their formal core diagrams. molecule $A$ (Figure $2 \mathrm{~d}$ ) is modestly ruffled and domed. while molecule $B$ (Figure 2e) is slightly saddled.

Table 1 contains the crystallographic details for all three crystalline forms. Results from the structural decomposition are shown in Table 3 and are consistent with the mean-plane diagrams for all porphyrin rings described above. Table 4 lists selected bond lengths and bond angles for each porphyrin and summarizes the inter-ring geometry for each dimer. Figure 3 illustrates a linear display of the skeletal deviations from the plane defined by the 24 -atom plane for all core conformations found among these $\left[\mathrm{Fe}(\mathrm{OEP})\left(\mathrm{O}_{2} \mathrm{C}_{2} \mathrm{Cl}_{3}\right)\right]$ solvates.

All attempts to remake the original unsolvated form were unsuccessful. Temperature dependent magnetic susceptibility measurements were carried out for the two solvated crystalline forms to investigate the spin-state differences between these complexes. Initial measurements on $\left[\mathrm{Fe}(\mathrm{OEP})\left(\mathrm{O}_{2} \mathrm{C}_{2} \mathrm{Cl}_{3}\right)\right] \cdot \mathrm{CHCl}_{3}$ resulted in a room temperature moment that was modestly elevated from that expected for a $S=5 / 2$ system. This suggests that the sample had lost a large portion of the chloroform solvate. Magnetic susceptibility measurements were then carried out for a portion of ground $\left[\mathrm{Fe}(\mathrm{OEP})\left(\mathrm{O}_{2} \mathrm{C}_{2} \mathrm{Cl}_{3}\right)\right] \cdot \mathrm{CHCl}_{3}$ which had been pumped to remove any remaining $\mathrm{CHCl}_{3}$ from the lattice. The room temperature moment (assuming no solvent remains) is $5.93 \mu_{\mathrm{B}}$ and the temperature dependence is representative of a high-spin iron(III) derivative. The room temperature moment for $\left[\mathrm{Fe}(\mathrm{OEP})\left(\mathrm{O}_{2} \mathrm{C}_{2} \mathrm{Cl}_{3}\right)\right] \cdot \mathrm{HO}_{2} \mathrm{C}_{2} \mathrm{Cl}_{3}$ is 5.58 $\mu_{\mathrm{B}}$ and the temperature dependence is typical for that of an admixed intermediate-spin complex. The temperature-dependent effective magnetic moments of $\left[\mathrm{Fe}(\mathrm{OEP})\left(\mathrm{O}_{2} \mathrm{C}_{2} \mathrm{Cl}_{3}\right)\right] \cdot \mathrm{CHCl}_{3}$ and $\left[\mathrm{Fe}(\mathrm{OEP})\left(\mathrm{O}_{2} \mathrm{C}_{2} \mathrm{Cl}_{3}\right)\right] \cdot \mathrm{HO}_{2} \mathrm{C}_{2} \mathrm{Cl}_{3}$ are plotted in Figure 4. 


\section{Discussion}

We report in this paper that more than one crystalline form of $\left[\mathrm{Fe}(\mathrm{OEP})\left(\mathrm{O}_{2} \mathrm{C}_{2} \mathrm{Cl}_{3}\right)\right]$ can be isolated, and that various ring conformations are found within these crystalline forms. The five-coordinate (octaethylporphinato)iron(III) derivatives reported here were not expected to exhibit differing core deformations since the substituents on porphyrin ring are not sterically: encumbering. Moreover. the axial ligand is constant and relatively small among the various forms. The most interesting but unfortunately not reproducible result is that of the unsolvated form, which was the first form isolated. In this form. two porphyrin core conformations can be identified.

Refinement of the crystal structure of this form clearly showed that several porphyrin core atoms did not occupy a single position. Thus. several atoms of the core occupy two positions. which we interpret as the result of two core conformations. Of the 24 atoms that make up the porphyrin core, 19 atoms are common in both conformers. The remaining 5 adjacent atoms of each core are unique to that individual conformer. ${ }^{\dagger}$

Conformation $\mathrm{A}$ (Figure $2 \mathrm{a}$ ) is best described as being slightly domed, having a maximum deviation from the 24-atom mean plane of $0.13 A$ and an average deviation of $0.06(4) A$. Conformation $\mathrm{B}$ (Figure 2b) is best described as being ruffed, with a maximum deviation of $0.31 A$ and an average deviation of $0.14(7) A$. The structural decomposition results show a striking difference in amounts of total out-of-plane distortion $\left(D_{\text {oop }}\right)$ and amounts of ring ruffing (ruf) between Conformations $A$ and $B$. The total out-of-plane displacement values are $0.229 A$ and $0.725 A$ for Conformations $A$ and $B$, respectively; the amounts of ruffing are $0.072 \AA$ and $0.681 \AA$, respectively. It is encouraging to note that the structural decomposition method was successful at describing. in detail. these two very different conformations at the same lattice site. There seems to be no apparent reason for the co-existence of two unique porphyrin rings with different core deformations at the same lattice site. The orientation of

\footnotetext{
'Several of the 19 atoms that are in both conformers must in reality occupy two positions that are too close to be crystallographically resolved. Hence, the descriptions of the conformers is somewhat approximate. The ORTEP diagran (Figure la) provides a visual description of the two conformers.
} 
the axial ligand with respect to the disordered portion of the core does not seem to influence macrocyclic conformations in $\left[\mathrm{Fe}(\mathrm{OEP})\left(\mathrm{O}_{2} \mathrm{C}_{2} \mathrm{Cl}_{3}\right)\right]$.

All subsequent attempts to isolate the unsolvated crystalline form of $\left[\mathrm{Fe}(\mathrm{OEP})\left(\mathrm{O}_{2} \mathrm{C}_{2} \mathrm{Cl}_{3}\right.\right.$ i] using the original solvent system $\left(\mathrm{CHCl}_{3}\right.$ /hexanes) resulted in the isolation of a new crystalline form. $\left.\mathrm{Fe}(\mathrm{OEP})\left(\mathrm{O}_{2} \mathrm{C}_{2} \mathrm{Cl}_{3}\right)\right] \cdot \mathrm{CHCl}_{3}$. In the new form, the core conformation can be described as being slightly ruffled (Figure 2c) with a maximum deviation of 0.13 and an average deviation of $0.06(t)$. The structural decomposition analysis revealed slight ruffing ( $u f=0.28 .5 \dot{A}$ ) of the porphyrin core.

A final attempt at crystallizing the first form (unsolvated complex) using a new solvent system $\left(\mathrm{CH}_{2} \mathrm{Cl}_{2} /\right.$ hexanes) yielded yet another crystalline form, $\left[\mathrm{Fe}(\mathrm{OEP})\left(\mathrm{O}_{2} \mathrm{C}_{2} \mathrm{Cl}_{3}\right)\right] \cdot \mathrm{HO}_{2} \mathrm{C}_{2} \mathrm{Cl}_{3}$. Surprisingly; the cell contains two independent porphyrins; each has a very different ring conformation. The core conformation of Molecule $A$ is best described as being ruffed (Figure 2d) with a maximum deviation of $0.23 A$ and an average deviation of $0.11(6) A$. Molecule $B$ can be described as slightly saddled (Figure $2 e$ ) with a maximum deviation of $0.13 \mathrm{~A}$ and an average deviation of $0.05(4) \AA$. At each of the two sites, a molecule of trichloroacetic acid (solvent) is hydrogen bonded to the oxygen atom of the axial ligand. The structural decomposition analysis revealed large differences in ring ruffing between the two molecules; ruf $=0.591 . \perp$ for Molecule $A$ and $r u f=0.121 \AA$ for $M$ Iolecule $B$. The decomposition also revealed slight saddling in Molecule B (sad $=0.205 \AA)$.

Upon comparison of the bond parameters of the five conformations (Table 4), it is apparent that the two independent molecules of $\left[\mathrm{Fe}(\mathrm{OEP})\left(\mathrm{O}_{2} \mathrm{C}_{2} \mathrm{Cl}_{3}\right)\right] \cdot \mathrm{HO}_{2} \mathrm{C}_{2} \mathrm{Cl}_{3}$ have shorter $\mathrm{Fe}-\mathrm{N}_{p}$ bond lengths, longer $\mathrm{Fe}_{\mathrm{O}} \mathrm{O}_{a x}$ bond lengths and a smaller iron displacement than $[\mathrm{Fe}(\mathrm{OEP})$ $\left.\left(\mathrm{O}_{2} \mathrm{C}_{2} \mathrm{Cl}_{3}\right)\right]$ and $\left[\mathrm{Fe}(\mathrm{OEP})\left(\mathrm{O}_{2} \mathrm{C}_{2} \mathrm{Cl}_{3}\right)\right] \cdot \mathrm{CHCl}_{3}$. The relationships between bond parameters and spin state for iron porphyrins have been well established [18], with high-spin iron centers having typical Fe- $\mathrm{N}_{p}$ and $\mathrm{Fe} \cdot \cdot \mathrm{Ct}$ distances of $\geq 2.045 \AA$ and $\geq 0.42 \AA$ respectively. The bond distance parameters for $\left[\mathrm{Fe}(\mathrm{OEP})\left(\mathrm{O}_{2} \mathrm{C}_{2} \mathrm{Cl}_{3}\right)\right]$ and $\left[\mathrm{Fe}(\mathrm{OEP})\left(\mathrm{O}_{2} \mathrm{C}_{2} \mathrm{Cl}_{3}\right)\right] \cdot \mathrm{CHCl}_{3}$ fit nicely into the high-spin characterization with $\mathrm{Fe}-\mathrm{N}_{p}$ bond distances of $2.045 \AA$ and $2.050 \AA$ respectively, 
and $\mathrm{Fe} \cdots \mathrm{Ct}$ distances of $0.45 \mathrm{~A}$ and $0.43 \mathrm{~A}$ respectirely. Also. the $\mathrm{Fe}-\mathrm{O}_{a x}$ bond lengths of $1.928(2) A$ and $1.935(2) A$ are typical for iron-oxygen bond distances in five-coordinate. highspin iron(III) derivatives. Ranges reported for five-coordinate admixed-spin iron(III) complexes are $1.961-2.038 \AA$ for $F e-N_{p}$ and $0.10-0.36 \AA$ for the iron atom displacement: the ralues vary according to the amount of $S=3 / 2.5 / 2$ character. These shorter bond parameters are indicative of a partially occupied $d_{x^{2}-y^{2}}$ antibonding orbital. The bond distance parameters for each independent molecule of $\left[\mathrm{Fe}(\mathrm{OEP})\left(\mathrm{O}_{2} \mathrm{C}_{2} \mathrm{Cl}_{3}\right)\right] \cdot \mathrm{HO}_{2} \mathrm{C}_{2} \mathrm{Cl}_{3}$ are indicative of partial $\mathrm{S}=3,2$ character. The average $F e-N_{p}$ distances are 2.029( $A$ ) $A$ and $2.036(6) A$ for Molecules $A$ and B. respectively; the iron displacements are $0.39 \AA$ and $0.37 \AA$ respectively. The $F e-O_{a x}$ bond distances are lengthened to $1.969(4) A$ for Molecule $A$ and $1.981(4) A$ for Molecule $B$. In order to investigate the possibility of spin-state differences among the crystalline forms, temperaturedependent magnetic susceptibility measurements were taken for $\left[\mathrm{Fe}(\mathrm{OEP})\left(\mathrm{O}_{2} \mathrm{C}_{2} \mathrm{Cl}_{3}\right)\right] \cdot \mathrm{CHCl}_{3}$ and $\left[\mathrm{Fe}(\mathrm{OEP})\left(\mathrm{O}_{2} \mathrm{C}_{2} \mathrm{Cl}_{3}\right)\right] \cdot \mathrm{HO}_{2} \mathrm{C}_{2} \mathrm{Cl}_{3}$.

The temperature-dependent magnetic susceptibility measurements for $\left[\mathrm{Fe}(\mathrm{OEP})\left(\mathrm{O}_{2} \mathrm{C}_{2} \mathrm{Cl}_{3}\right)\right] \cdot-$ $\mathrm{CHCl}_{3}$ clearly show that it is a high-spin iron(III) system (Figure 1). The magnetic measurements for $\left[\mathrm{Fe}(\mathrm{OEP})\left(\mathrm{O}_{2} \mathrm{C}_{2} \mathrm{Cl}_{3}\right)\right] \cdot \mathrm{HO}_{2} \mathrm{C}_{2} \mathrm{Cl}_{3}$ (also shown in Figure 4 ) resemble that of an admixed intermediate-spin system. The data can be fitted with a modified admixed intermediate-spin Waltempo model [19] resulting in a ground state multiplet with about $78 \% \mathrm{~S}=5 / 2$ character and $22 \% \mathrm{~S}=3 / 2$ character. Admixed intermediate-spin compounds have been found to exhibit varying amounts of $S=3 / 2$ character. many depending on the nature of the axial ligand [20-26]. For example, $\left[\mathrm{Fe}(\mathrm{TPP})\left(\mathrm{O}_{2} \mathrm{C}_{2} \mathrm{~F}_{3}\right)\right][27]$ is pure $\mathrm{S}=5 / 2$, while $\left[\mathrm{Fe}(\mathrm{TPP})\left(\mathrm{OClO}_{3}\right)\right] \cdot 1 / 2(m-x y \cdot$ lene $)$ $[20]$ is approximately $55 \% \mathrm{~S}=3 / 2$.

Subtle solid-state affects have also been attributed to promoting a change in spin state. González and Wilson [28] reported that a triclinic form of [ $\left.\mathrm{Fe}(\mathrm{TPP})\left(\mathrm{OSO}_{2} \mathrm{CF}_{3}\right)\right]$ contains two independent molecules in the unit cell; each site is magnetically distinct. It was postulated that the hydrogen bonding network that was found only at one site could be a factor that stabilizes the spin state of that iron center. For the two pure $S=5 / 2$ systems reported in this paper 
( $\left.\mathrm{Fe}(\mathrm{OEP})\left(\mathrm{O}_{2} \mathrm{C}_{2} \mathrm{Cl}_{3}\right)\right]$ and $\left.\left[\mathrm{Fe}(\mathrm{OEP})\left(\mathrm{O}_{2} \mathrm{C}_{2} \mathrm{Cl}_{3}\right)\right] \cdot \mathrm{CHCl}_{3}\right)$. all intramolecular and intermolecular contacts seem to be at or in excess of the van der Waals radii of the atoms involved. The axial ligands of both molecules of $\left[\mathrm{Fe}(\mathrm{OEP})\left(\mathrm{O}_{2} \mathrm{C}_{2} \mathrm{Cl}_{3}\right)\right] \cdot \mathrm{HO}_{2} \mathrm{C}_{2} \mathrm{Cl}_{3}$ are involved in hydrogen bonding to a nearby molecule of $\mathrm{HO}_{2} \mathrm{C}_{2} \mathrm{Cl}_{3}$ (solvent). The $\mathrm{O}(2)$ atom of the axial ligand is $2.63 \mathrm{~A}$ and 2.60 A from $O(S 1)$ in . Molecules $A$ and $B$. respectively: these are in accord with relatively strong hydrogen bonds. It is possible that the hydrogen bond interactions provide stability for partial $\mathrm{S}=3 / 2$ character by decreasing the field strength of the axial ligand.

Intermolecular $\pi-\pi$ interactions are commonly found in metallooctaethylporphyrinates. Solid-state $\pi-\pi$ dimer formation is seen in all crystalline forms of $\left[\mathrm{Fe}(\mathrm{OEP})\left(\mathrm{O}_{2} \mathrm{C}_{2} \mathrm{Cl}_{3}\right)\right]$ (Table 4). All inter-ring parameters are consistent with the Group I (Intermediate) class. as defined by Scheidt and Lee [29] in 1987. The modest $\mathrm{Fe} \cdots \mathrm{Fe}$ separation of $5.45 \mathrm{~A}$ in $\left[\mathrm{Fe}(\mathrm{OEP})\left(\mathrm{O}_{2} \mathrm{C}_{2} \mathrm{Cl}_{3}\right)\right]$ $\mathrm{CHCl}_{3}$ accounts for the weak antiferromagnetic coupling, $J=0.5 \mathrm{~cm}^{-1} \ddagger$

Each independent magnetic center of $\left[\mathrm{Fe}(\mathrm{OEP})\left(\mathrm{O}_{2} \mathrm{C}_{2} \mathrm{Cl}_{3}\right)\right] \cdot \mathrm{HO}_{2} \mathrm{C}_{2} \mathrm{Cl}_{3}$ is involved in dimer formation. This is in contrast to the triclinic [ $\left.\mathrm{Fe}(\mathrm{IPP})\left(\mathrm{OSO}_{2} \mathrm{CF}_{3}\right)\right]$ system mentioned above [28] which contains two magnetically distinct sites, one of which is involved in strong $\pi-\pi$ interactions and the other is not. Molecules $\mathrm{A}$ and $\mathrm{B}$ of $\left[\mathrm{Fe}(\mathrm{OEP})\left(\mathrm{O}_{2} \mathrm{C}_{2} \mathrm{Cl}_{3}\right)\right] \cdot \mathrm{HO}_{2} \mathrm{C}_{2} \mathrm{Cl}_{3}$ have $\mathrm{Fe}$... Fe distances of $5.58 \mathrm{~A}$ and $5.61 \mathrm{~A}$ respectively, with weak antiferromagnetic coupling, $\mathrm{J}=$ $0.76 \mathrm{~cm}^{-1}$

The Raman spectrum obtained for $\left[\mathrm{Fe}(\mathrm{OEP})\left(\mathrm{O}_{2} \mathrm{C}_{2} \mathrm{Cl}_{3}\right)\right] \cdot \mathrm{HO}_{2} \mathrm{C}_{2} \mathrm{Cl}_{3}$ shows a five-coordinate. high-spin $\mathrm{Fe}$ (III) heme based on the frequencies of the structure-sensitive Raman lines $\left(\nu_{4}\right.$ at $1368, \nu_{3}$ at 1487 , and $\nu_{2}$ at $1561 / 1572 \mathrm{~cm}^{-1}$ ) [30]. Highly constrained curve fitting with two sublines for the $\nu_{10}$ Raman line [31] give two equal-area, equal-height lines at 1624 and 1609

\footnotetext{
:The Hamiltonian used for the $\mathrm{S}=\mathrm{S}^{\prime}=3,2$ jystem is$$
H=D\left[\left(S_{z}^{2}-S(S+1)\right)+\left(S_{z}^{\prime 2}-S^{\prime}\left(S^{\prime}+1\right)+9,3 \vec{H} \cdot\left(\vec{S}+\vec{S}^{\prime}\right)+J\left(\vec{S} \cdot \vec{S}^{\prime}\right)\right.\right.
$$

where $D$ is the zero-field splitting parameter. For the mixed-spin system, the Hamiltonian is

$$
H=H_{0}+H_{0}^{\prime}+\zeta\left(\vec{L} \cdot \vec{S}+\vec{L}^{\prime} \cdot \vec{S}^{\prime}\right)+g, 3 \vec{H} \cdot\left(\vec{S}+\vec{S}^{\prime}\right)+J\left(\vec{S} \cdot \vec{S}^{\prime}\right)
$$

where $H_{0}$ and $H_{0}^{\prime}$ provide the splitting between the sextet and quartet states, and $\zeta$ is the spin-orbit coupling parameter.
} 
$\mathrm{cm}^{-1}$. Assuming a correlation between ruffing and frequency for high-spin $\mathrm{Fe}($ III) hemes like the one for low-spin $\mathrm{Fe}(\mathrm{III})$ [31], we would expect only about $6 \doteq 2 \mathrm{~cm}^{-1}$ difference in the frequencies of $\nu_{10}$ for the two structures in the crystal [31]. The difference that we see is

$16 \pm 3 \mathrm{~cm}^{-1}$. The small doming of the predominantly ruffled structure might further enhance this frequency difference [32]. It is interesting that the frequency of one subline is close to [FeProtoP $(\mathrm{Cl})][30]$, while the other is much lower. consistent with the ruffled form present in the crystal. Further work on the system is planned when a more sensitive (CCD) system becomes available.

Subtle changes in porphyrin ring conformation have recently been noted for a series of organosilicon porphyrins [33]. A relatively planar conformation was found in $\left[\mathrm{Si}(\mathrm{TPP})\left(\mathrm{CH}=\mathrm{CH}_{2}\right)_{2}\right]$. a moderately ruffed conformation for $\left[\mathrm{Si}(\mathrm{TPP})\left(\mathrm{C}_{\hat{\sigma}} \mathrm{H}_{5}\right)_{2}\right]$. and a slightly waved conformation for $\left[\mathrm{Si}(\mathrm{TPP})\left(\mathrm{C} \equiv \mathrm{CC}_{6} \mathrm{H}_{5} \mathrm{O}_{2}\right)\right]$. In this case, it appears that the stereoelectronic features of the axial ligands may influence the conformational structure of the porphyrin ring.

\section{Summary}

Substantial conformational diversity is found among various solvates of $\left[\mathrm{Fe}(\mathrm{OEP})\left(\mathrm{O}_{2} \mathrm{C}_{2} \mathrm{Cl}_{3}\right)\right]$. The unsolvated $\left[\mathrm{Fe}(\mathrm{OEP})\left(\mathrm{O}_{2} \mathrm{C}_{2} \mathrm{Cl}_{3}\right)\right]$ structure showed two unique porphyrin core conformations at the same lattice site; one conformation was slightly domed, while the other conformation was modestly $\mathrm{S}_{4}$-ruffled. The chloroform solvate, $\left[\mathrm{Fe}(\mathrm{OEP})\left(\mathrm{O}_{2} \mathrm{C}_{2} \mathrm{Cl}_{3}\right)\right] \cdot \mathrm{CHCl}_{3}$, has a slightly ruffied core. Finally, the trichloroacetic acid solvate contains two independent porphyrins; one molecule is slightly saddled while the other is modestly ruffled. The structural decomposition analysis revealed consistent results when compared to the 21-atom mean-plane diagrams. Although octaethylporphyrinates are capable of adopting various core conformations, severely distorted cores are rarely encountered because of the small steric constraints at the periphery. It appears that solid-state affects are responsible for the changes in core conformation among these iron octaethylporphyrinate complexes. 


\section{Supplementary material.}

Tables S1-S15 give complete crystallographic details. complete listings of bond distances and angles. anisotropic temperature factors, and fxed hydrogen atom positions for all complexes. Ordering information is given on any current masthead page.

\section{Acknowledgements}

We thank the National Institutes of Health for support of this research under Grant G.I$38+01$ (W.R.S.) and for the purchase of X-ray instrumentation under Grant RR-06709. We also thank the National Science Foundation for the purchase of the SQUID equipment under Grant D.IR-9703732. W.R.S. and T.J.N. thank K. Barkigia for advice in drawing Figure 3. Sandia is a multiprogram laboratory operated by Sandia Corporation. a Lockheed Martin Company. for the United States Department of Energy under Contract DE-AC0 $4-9+$ QR85000. 


\section{References and Notes}

(1) (a) Shelnutt. J. A.: Song, X.-Z.; Ma. J.-G.: Jia. S.-L.: Jentzen. W.: Medforth, C. J. Chim. Soc. Rev. 1998, 27. 31. (b) Jentzen. W.: Ma. J.-G.: Shelnutt. J. A. Biophys. J. 1998. 4 . 753. (c) Hobbs. J. D.; Sheinutt. J. A. J. Protein Chem. 1995. 14. 19.

(2) (a) Barkigia. K. .I.: Chantranupong, L.: Smith. K. M.; Fajer. J. J. Am. Chem. 5oc. 1988. 110. 7566. (b) Barkigia. K. M.: Gottfried. D. S.: Boxer. S. G.: Fajer. J. J. Am. Chem. Ear. $1989,111.6+14$.

(3) Barkigia, K. M.: Dolores Berber, M.; Fajer. J.: Medforth, C. J.: Renner. II. II.: Smi:n. K. II. J. Am. Chem. Soc. 1990, 112, 8851 .

(t) Cheng, R.-J.; Chen, Y.-R.; Chuang. C.-E. Heterocycles, 1992. 34. I.

(5) Song, X.-Z.; Jentzen, W.: Jaquinod, L.: Khoury, R. G.: Medforth, C. J.; Jia. J.-G.: Smith. K. .I.; Shelnutt. J. A. Inorg. Chem. 1998. 37. 2117.

(6) Sparks, J. A.; Medforth, C. J.: Park, M.-S.; Chamberlain. J. R.; Ondrias, M. R.; Senge. M. O.; Smith, K. M.; Shelnutt. J. A. J. Am. Chem. Soc. 1993, 115. 581.

(7) Anderson, K. K.; Hobbs, J. D.; Luo, L.: Stanley, K. D.; Quirke, J. M. E.; Shelnutt. J. A J. Am. Chem. Soc. 1993. 115, 12346.

(8) Jentzen, W.; Song, X.-Z.; Shelnutt. J. A. J. Phys. Chem. B 1997, 101, 1684.

(9) Abbreviations used in this paper: OEP, octaethylporphyrin; TPP, tetraphenylporphyrin: SQUID, Superconducting Quantum Interference Device.

(10) Adler, A. D.; Longo, F. R.: Kampas. F.; Kim, J. J. Inorg. Nucl. Chem. 1970. 32, 2443.

(11) Blessing, R. H. Crystallogr. Rev. 1987. 1, 3.

(12) Scheidt, W. R.; Turowska-Tyrk. I. Inorg. Chem. 1994, 33, 1314.

(13) Programs used in this study included SHELXS-86 (Sheldrick, G. M.; Acta Crystallogr.. Sect. A 1990, A46, 467); SHELXL-93 (Sheldrick, G. M.; J. Appl. Cryst., in preparation): and local modifications of ORTEP (Johnson, C. K., ORTEP: A Fortran Thermal-Ellipsoid Plot Program For Crystal Structure Illustrations, 1970, Oak Ridge National Laboratory, USA). Scattering factors were take from International Tables for Crystallography, Vol. C, Ed. Wilson, A.J.C., Kluwer Academic Publishers, Dordrecht, 1992.

(14) Le Page, Y. J. Appl. Cryst. 1988, 21, 983; Le Page, Y. J. Appl. Cryst. 1987, 20, 264. 
(15) Sutter. T. P. G.: Hambright. P.: Thorpe, A. N.; Quoc. N. Inorg. Chim. Acta 1992. 19.5. 131.

(16) Selwood. P. W. Magnetochemistry: Interscience: New York. 1956: Chapter 2.

(1i) Earnshaw. A. Introduction to Magnetochemistry: Academic: London. 1968: Chapter 1.

(13) Scheidt. II. R.: Reed. C. A. Chem. Rev.. 1981. 81. 543.

(19) Maltempo. .I. Mf. J. Chem. Phys. 1974. 61. 2540.

(20) Reed, C. A.; Mashiko. T.: Bentley. S. P: Kastner: M. E.; Scheidt. W. R.: Spartalian. K.: Lang, G. J. Am. Chem. Soc. 1979. 101, 2948.

(21) Scheidt. W. R.; Geiger, D. K.; Lee, Y. J.; Reed. C. A.; Lang, G. Inorg. Chem. 1987. 26. 1039.

(22) Shelly. K.: Reed. C. A.: Lee, Y. A.; Scheidt. W. R. J. Am. Chem. Soc. 1986, 108. 311 i.

(23) Shelly, K.: Bartczak. T.; Scheidt, W. R.: Reed, C. A. Inorg. Chem. 1985. 24. 4325.

(21) Gupta. G. P.; Lang, G.; Lee. Y. J.; Scheidt, W. R.; Shelly, K.; Reed. C. A. Inorg. Chem. $1987,26,3022$.

(25) Masuda, H.; Taga. T.; Osaki, K.; Sugimoto, H; Yoshida, Z.; Ogoshi, H Inorg. Chem. 1980. 19. 950 .

(26) Kastner, M. E.; Scheidt, W. R.; Mashiko, T.; Reed, C. A. J. Am. Chem. Soc. 1978, 100, 666.

(27) Moy: S. A.; González, J. A.; Wilson, L. J. Acta Cryst., 1995, 51, 1490.

(28) González, J. A.; Wilson, Lon. J. Inorg. Chem. 1994, 33, 1543.

(29) Scheidt. W. R; Lee, Y. L. In Structure and Bonding 64-Metal Complexes with Tetrapyrolle Ligands I; Buchler, J. W., Ed.: Springer-Verlag: New York, 1987; pp. 1-70.

(30) Spiro, T. G. in Iron Porphyrins. Part Tu'o (Lever, A. B. P., and Gray, H. B.. Ed.) Chapter 3. Addison-Wesley Publishing Company. Reading, MA. 1983.

(31) Ma, J.-G.; Zhang, J.; Franco, R.; Jia, S.-L.; Moura, I.; Moura, J. J. G.; Kroneck, P. M. H.; Shelnutt, J. A. Biochemistry, in press.

(32) Song, X.-Z.; Jentzen, W.; Jia, S.-L.; Jaquinod, L.; Nurco, D. J.; Medforth, C. J.; Smith, K. M.; Shelnutt, J. A. J. Am. Chem. Soc. 1996, 118, 12975.

(33) Zheng, J.Y.; Konishi, K.; Aida, T Inorg. Chem. 1998, 37, 2591. 
Figure 1. ORTEP diagrams of (a.b) [nsolvated $\mathrm{Fe}(\mathrm{OEP})\left(\mathrm{O}_{2} \mathrm{C}_{2} \mathrm{Cl}_{3}\right)$ ] displaying the wo porphyrin ring conformations. (c) Solvated $\left[\mathrm{Fe}(\mathrm{OEP})\left(\mathrm{O}_{2} \mathrm{C}_{2} \mathrm{Cl}_{3}\right)\right] \cdot \mathrm{CHCl}_{3}$. (d) Solrated $\mathrm{Fe}(\mathrm{OEP})\left(\mathrm{O}_{2} \mathrm{C}_{2} \mathrm{Cl}_{3}\right) \cdot \mathrm{HO}_{2} \mathrm{C}_{2} \mathrm{Cl}_{3}$, molecule $A$. (e) Solvated $\mathrm{Fe}(\mathrm{OEP})\left(\mathrm{O}_{2} \mathrm{C}_{2} \mathrm{Cl}_{3}\right) ;-$ $\mathrm{HO}_{2} \mathrm{C}_{2} \mathrm{Cl}_{3}$, molecule B. Ellipsoids are drawn to illustrate $50 \%$ probability surfaces.

Figure 2. Unique 2t-atom mean-plane diagrams of (a) Unsolvated $\left[\mathrm{Fe}(\mathrm{OEP})\left(\mathrm{O}_{2} \mathrm{C}_{2} \mathrm{Cl}_{3}\right)\right]$. conformation A. (b) Unsolvated $\left[\mathrm{Fe}(\mathrm{OEP})\left(\mathrm{O}_{2} \mathrm{C}_{2} \mathrm{Cl}_{3}\right)\right]$, conformation $\mathrm{B}$. (c) Solvated $\left[\mathrm{Fe}(\mathrm{OEP})\left(\mathrm{O}_{2} \mathrm{C}_{2} \mathrm{Cl}_{3}\right)\right] \cdot \mathrm{CHCl}_{3}$. (d) Solvated $\left[\mathrm{Fe}(\mathrm{OEP})\left(\mathrm{O}_{2} \mathrm{C}_{2} \mathrm{Cl}_{3}\right)\right] \cdot \mathrm{HO}_{2} \mathrm{C}_{2} \mathrm{Cl}_{3}$. molecule A. (e) Solvated $\left[\mathrm{Fe}(\mathrm{OEP})\left(\mathrm{O}_{2} \mathrm{C}_{2} \mathrm{Cl}_{3}\right)\right] \cdot \mathrm{HO}_{2} \mathrm{C}_{2} \mathrm{Cl}_{3}$. molecule $\mathrm{B}$.

Figure 3. Linear display of the skeletal deviations from the plane defined by the $2 t$-atom plane, in $A \times 10^{2}$. Illustrated are (a) and (b) the two unique core conformations of $\left[\mathrm{Fe}(\mathrm{OEP})\left(\mathrm{O}_{2} \mathrm{C}_{2} \mathrm{Cl}_{3}\right)\right]$ (c) $\left[\mathrm{Fe}(\mathrm{OEP})\left(\mathrm{O}_{2} \mathrm{C}_{2} \mathrm{Cl}_{3}\right)\right] \cdot \mathrm{CHCl}_{3}$ (d) and (e) the two independent molecules of $\left[\mathrm{Fe}(\mathrm{OEP})\left(\mathrm{O}_{2} \mathrm{C}_{2} \mathrm{Cl}_{3}\right)\right] \cdot \mathrm{HO}_{2} \mathrm{C}_{2} \mathrm{Cl}_{3}$.

Figure 4. Comparison of observed and calculated values of $\mu_{\text {eff }} /$ monomer vs $\mathrm{T}$ for (a) $\left[\mathrm{Fe}(\mathrm{OEP})\left(\mathrm{O}_{2} \mathrm{C}_{2} \mathrm{Cl}_{3}\right)\right] \cdot \mathrm{CHCl}_{3}$ and (b) $\left[\mathrm{Fe}(\mathrm{OEP})\left(\mathrm{O}_{2} \mathrm{C}_{2} \mathrm{Cl}_{3}\right)\right] \cdot \mathrm{HO}_{2} \mathrm{C}_{2} \mathrm{Cl}_{3}$. The solid lines are model calculations assuming pairwise spin coupling. The parameters used are (a) $\mathrm{S}=5 / 2$ with axial zero-field splitting $\mathrm{D}=8.3 \mathrm{~cm}^{-1}$ and antiferromagnetic coupling with $\mathrm{J}=0.5 \mathrm{~cm}^{-1}$. and (b) mixed spin $(5 / 2.3 / 2)$ with the $3 / 2$ excited-state multiplet at $280 \mathrm{~cm}^{-1}$, spin-orbit coupling $(\zeta)=195 \mathrm{~cm}^{-1}$, and antiferromagnetic coupling with $\mathrm{J}=0.75 \mathrm{~cm}^{-1}$. 

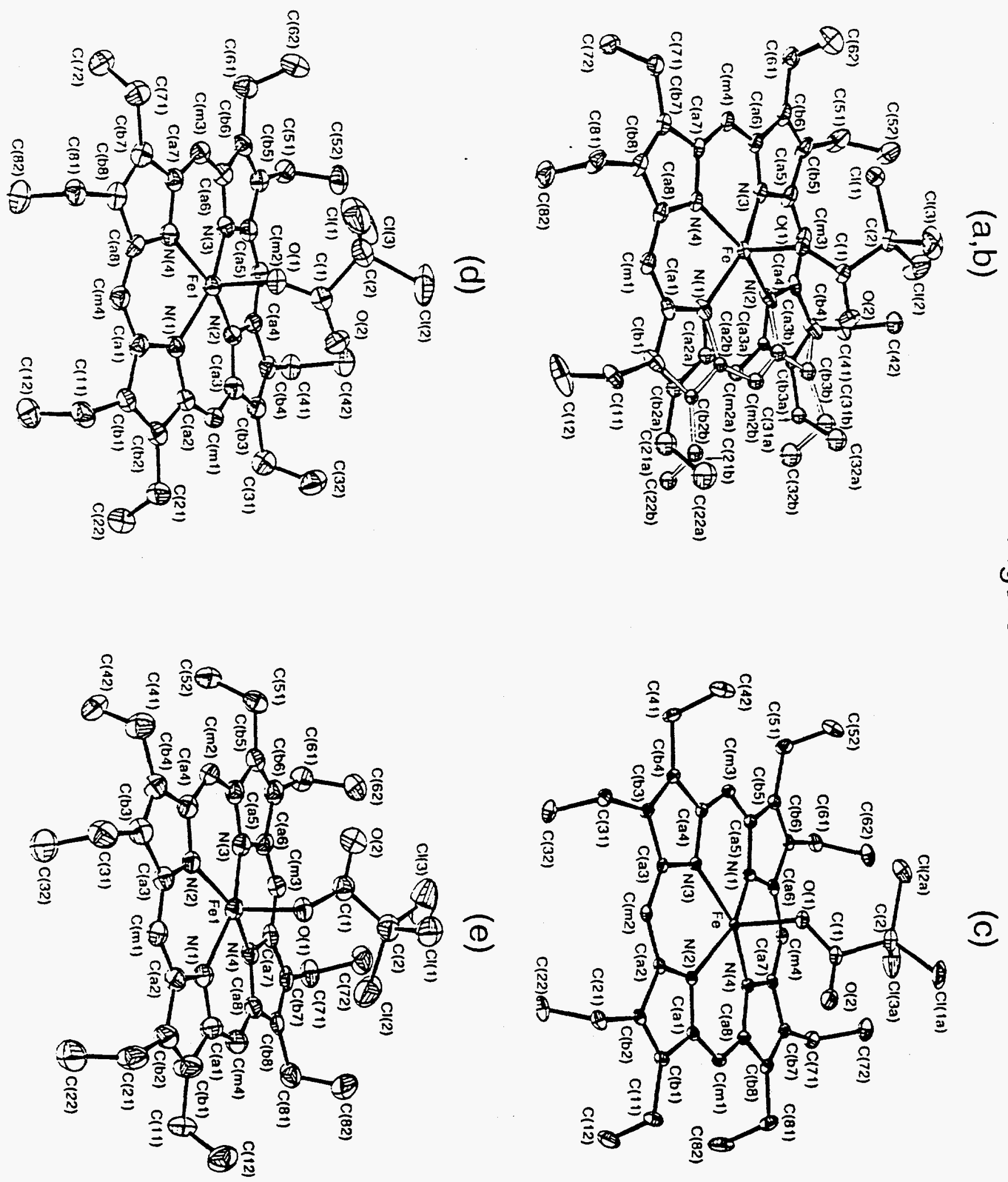
(a)

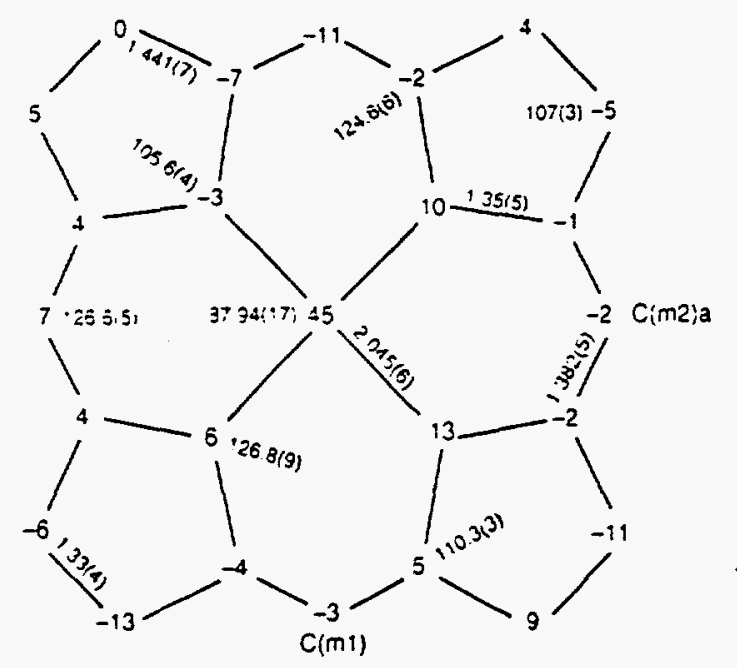

Figure 2

(b)

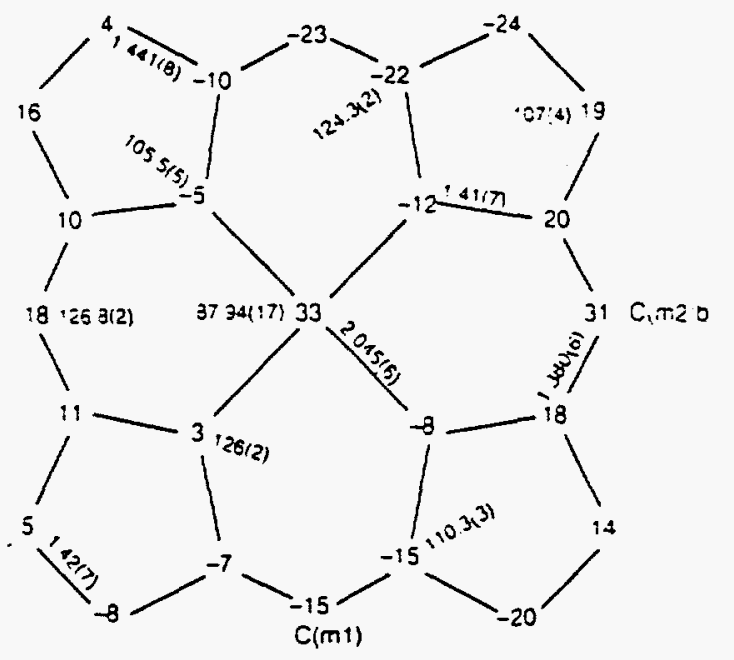

(c)

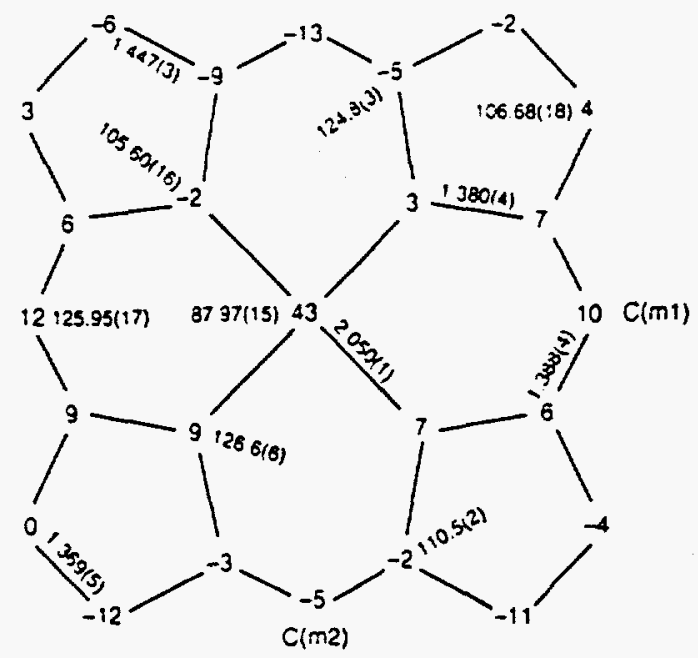

(d)

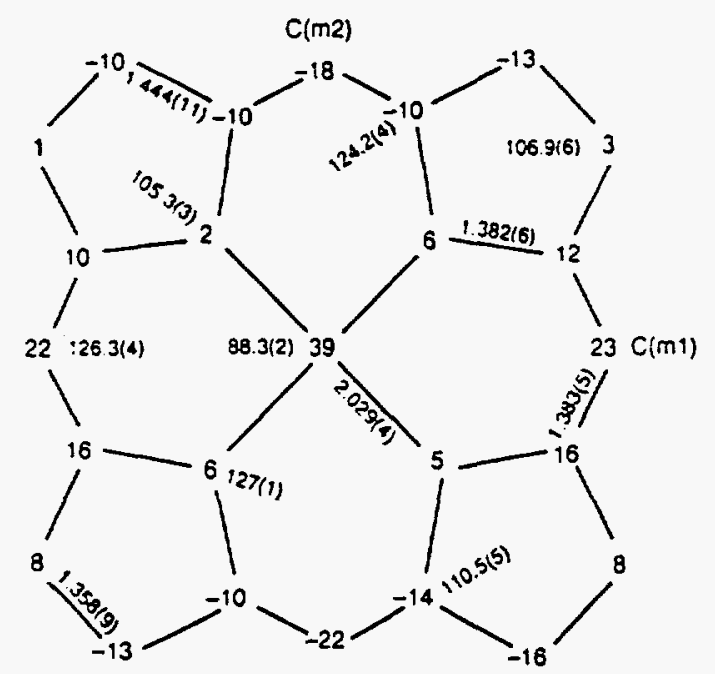

(e)

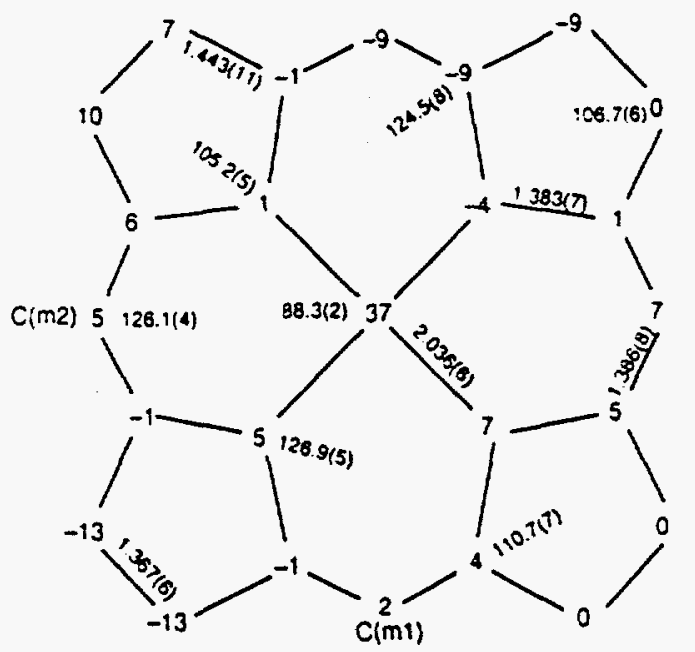


Displixisurent

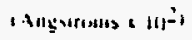

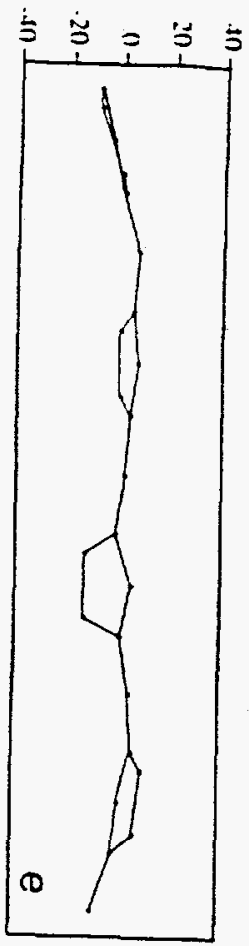

Displexinem

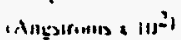

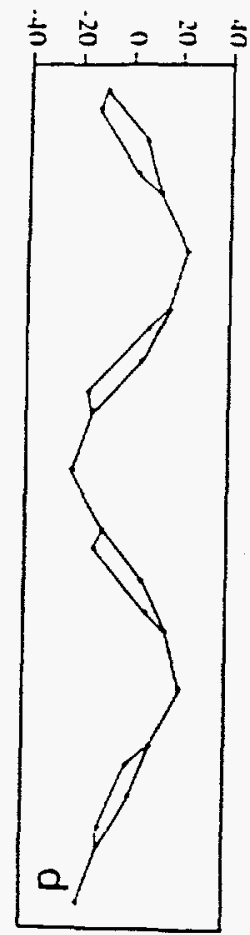

Displecerneat

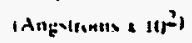

$5 \stackrel{5}{5}=5$

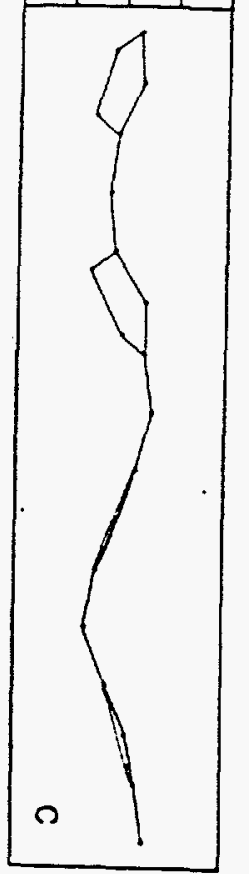

Dinplaxine:m

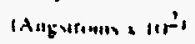

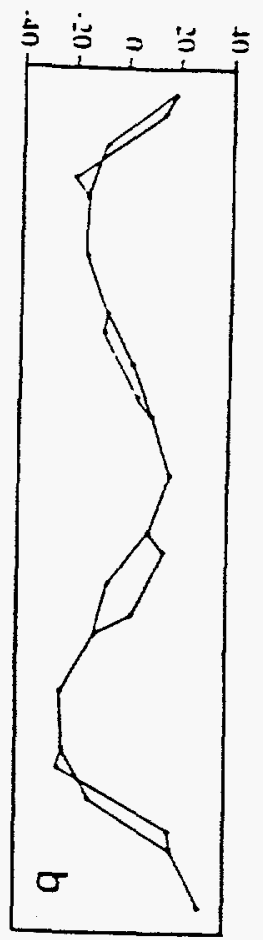

Diplaxi:ixen

, ins?

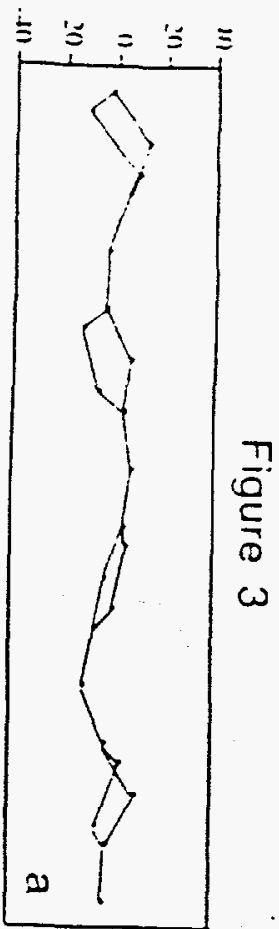

$\mu_{\text {cti }}$

$\mu_{\text {etI }}$

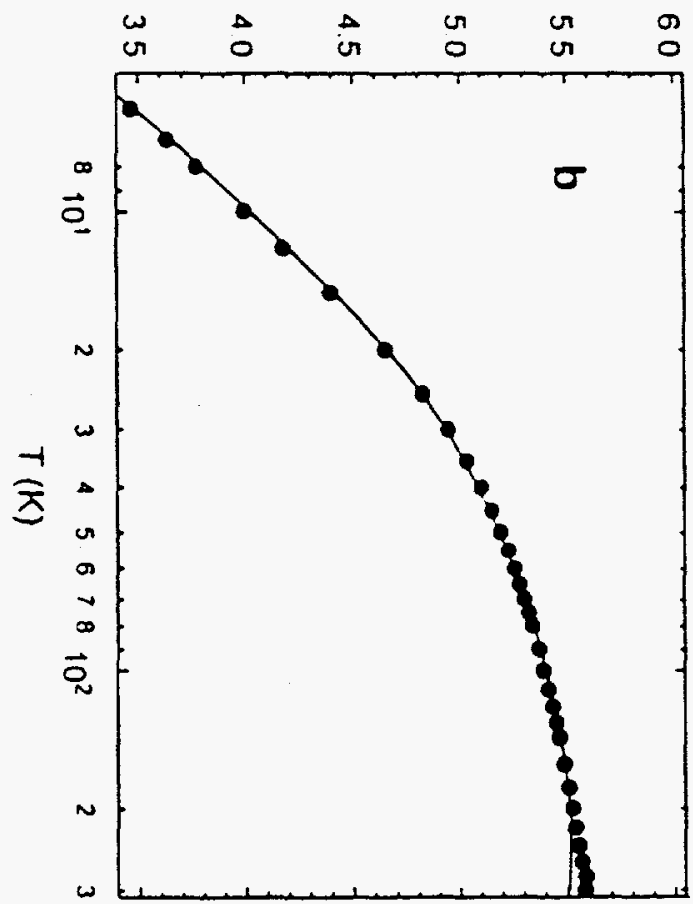

$\stackrel{1}{70}$ 
Table 1. Crystallographic details for $\left[\mathrm{Fe}(\mathrm{OEP})\left(\mathrm{O}_{2} \mathrm{C}_{2} \mathrm{Cl}_{3}\right)\right]$ complexes.

\begin{tabular}{|c|c|c|c|}
\hline Molecule & $\left.\mathrm{Fe}(\mathrm{OEP})\left(\mathrm{O}_{2} \mathrm{C}_{2} \mathrm{Cl}_{3}\right)\right]$ & $\begin{array}{c}\left.\mathrm{Fe}(\mathrm{OEP})\left(\mathrm{O}_{2} \mathrm{C}_{2} \mathrm{Cl}_{3}\right)\right] \\
\cdot \mathrm{CHCl}_{3}\end{array}$ & $\begin{array}{c}\mathrm{Fe}(\mathrm{OEP})\left(\mathrm{O}_{2} \mathrm{C}_{2} \mathrm{Cl}_{3}\right. \\
\cdot \mathrm{HO}_{2} \mathrm{C}_{2} \mathrm{Cl}_{3}\end{array}$ \\
\hline Formula & $\mathrm{Fe} \mathrm{N}_{4} \mathrm{Cl}_{3} \mathrm{O}_{2} \mathrm{C}_{38} \mathrm{H}_{44}$ & $\mathrm{Fe}_{4} \mathrm{Cl}_{6} \mathrm{O}_{2} \mathrm{C}_{39} \mathrm{H}_{45}$ & $\mathrm{Fe}_{4} \mathrm{Cl}_{5} \mathrm{O}_{4} \mathrm{C}_{40} \mathrm{H}_{45}$ \\
\hline EII. amu & 7.50 .97 & 870.34 & 914.35 \\
\hline a. $A$ & $14.784(4)$ & $12.323(1)$ & $13.1+3(.3)$ \\
\hline b. $A$ & $13.67+(1)$ & $13.062(3)$ & $13.45 .5(3)$ \\
\hline c. $A$ & $17.5+11(5)$ & $14.327(2)$ & $23.761(5)$ \\
\hline$\alpha \cdot \operatorname{deg}$ & $\longrightarrow$ & $89.32(1)$ & $90 . \bar{\imath}(3)$ \\
\hline 3. deg & $90.67(1)$ & $113.36(2)$ & $91.24(3)$ \\
\hline$\because$ deg & $\longrightarrow$ & $105.26(1)$ & $92.36(3)$ \\
\hline$V \cdot \dot{A}^{3}$ & $3545.8(14)$ & $2031.3(6)$ & $4198.5(15)$ \\
\hline Crystal system & monoclinic & triclinic & triclinic \\
\hline Space Group & $P 2_{1} / n$ & $P \bar{l}$ & $P \overline{1}$ \\
\hline$Z$ & 4 & 2 & 4 \\
\hline$D_{c}, g / \mathrm{cm}^{3}$ & 1.41 & 1.42 & 1.45. \\
\hline$F(000)$ & 1572 & 902 & 1592 \\
\hline$\mu, \mathrm{mm}^{-1}$ & 0.692 & 0.805 & 0.756 \\
\hline Absorption correction & $\psi$ scans & - & DIF.ABS \\
\hline Transmission coeff. & $1.00-0.81$ & $\longrightarrow$ & $1.00-0.756$ \\
\hline Radiation $(\bar{\lambda}, A)$ & $\operatorname{MoK} \alpha(0.71073)$ &. $\mathrm{IoK} \alpha(0.71073)$ & $\operatorname{MoK} \alpha(0.71073)$ \\
\hline Temperature, $\mathrm{K}$ & $124(2)$ & $127(2)$ & $12 \pi(2)$ \\
\hline Diffractometer & Enraf-Nonius CAD4 & Enraf-Nonius FAST & Enraf-Nonius FAST \\
\hline$\theta$ Range, deg & $2.03-27.41$ & $2.24-29.78$ & $2.21-29.86$ \\
\hline Total data collected & 11269 & 19056 & 39959 \\
\hline Unique data & $7917\left(R_{\mathrm{int}}=0.0601\right)$ & $10055\left(R_{\mathrm{int}}=0.073\right)$ & $21188\left(R_{\text {int }}=0.120\right)$ \\
\hline $\begin{array}{l}\text { Enique observed data } \\
\qquad[I>2 \sigma(I)]\end{array}$ & 6527 & 8930 & 9782 \\
\hline Refinement method & on $F^{2}$ (SHEL.XL) & on $F^{2}$ (SHELXL) & on $F^{2}$ (SHELXL) \\
\hline Variables refined & 431 & 490 & 1045 \\
\hline $\max (\Delta \rho), e / A^{3}$ & 0.950 & 0.856 & 0.747 \\
\hline $\min (\Delta \rho), \mathrm{e} / \AA^{3}$ & -0.822 & -0.827 & -0.672 \\
\hline$R$ indices $[\mathrm{I}>2 \sigma(\mathrm{I})]$ & $\begin{array}{l}R_{1}=0.0610 \\
w R_{2}=0.1390\end{array}$ & $\begin{array}{l}R_{1}=0.0429 \\
u R_{2}=0.1186\end{array}$ & $\begin{array}{l}R_{1}=0.0913 \\
w R_{2}=0.1988\end{array}$ \\
\hline $\mathrm{R}$ indices (all data) & $\begin{array}{l}R_{1}=0.0732 \\
w R_{2}=0.1514\end{array}$ & $\begin{array}{l}R_{1}=0.0519 \\
w R_{2}=0.1548\end{array}$ & $\begin{array}{l}R_{1}=0.1989 \\
w R_{2}=0.2633\end{array}$ \\
\hline Goodness-of-fit on $F^{2}$ & 1.062 & 1.052 & 1.022 \\
\hline
\end{tabular}


Table 2. Atomic Coordinates and Equivalent Isotropic Displacement Parameters $\left(A^{2}\right)$ for $\left.\mathrm{Fe}(\mathrm{OEP})\left(\mathrm{O}_{2} \mathrm{C}_{2} \mathrm{Cl}_{3}\right)\right]$ Complexes $^{a}$

(a)! $\mathrm{Fe}(\mathrm{OEP})\left(\mathrm{O}_{2} \mathrm{C}_{2} \mathrm{Cl}_{3}\right)$ !

\begin{tabular}{|c|c|c|c|c|}
\hline atom & $x$ & $y$ & $z$ & {$[\because(\mathrm{eq})$} \\
\hline $\mathrm{Fe}$ & $0.92245(3)$ & $0.99240(3)$ & $0.13793(2)$ & $0.017+1)$ \\
\hline$\therefore(1)$ & $0.5403(2)$ & $0.8728(2)$ & $0.12515(14)$ & $0.0241(5)$ \\
\hline$\therefore(2)$ & $1.0245(2)$ & $0.9118(2)$ & $0.09221(14)$ & $0.0251(5)$ \\
\hline$X(3)$ & $0.9919(2)$ & $1.115 .5(2)$ & $0.106+1(14)$ & $0.0229(.5)$ \\
\hline$N(t)$ & $0.8083(2)$ & $1.0759(2)$ & $0.14190(13)$ & $0.0203(5)$ \\
\hline$C(a 1)$ & $0.748 \pi(2)$ & $0.867 \sharp(2)$ & $0.1366(2)$ & $0.0221(6)$ \\
\hline$C(a t)$ & $1.1097(2)$ & $0.9438(2)$ & $0.07248(15)$ & $0.0226(6)$ \\
\hline$C(a 5)$ & $1.0819(2)$ & $1.1202(2)$ & $0.0881(2)$ & $0.0281(6)$ \\
\hline$C(a 6)$ & $0.9663(2)$ & $1.2095(2)$ & $0.1220(2)$ & $0.0232(6)$ \\
\hline$C(a i)$ & $0.8053(2)$ & $1.1768(2)$ & $0.1+91(2)$ & $0.0220(6)$ \\
\hline$C(a \overline{8})$ & $0.7203(2)$ & $1.0444(2)$ & $0.1501(2)$ & $0.0230(6)$ \\
\hline$C(b 1)$ & $0.7192(2)$ & $0.7665(2)$ & $0.1365(2)$ & $0.0299(\bar{T})$ \\
\hline$C(b+1)$ & $1.1685(2)$ & $0.8628(2)$ & $0.0 .591(2)$ & $0.0312(\bar{i})$ \\
\hline$C(b \overline{)})$ & $1.1143(2)$ & $1.2195(2)$ & $0.0934(2)$ & $0.0340(8)$ \\
\hline$C(b 6)$ & $1.0423(2)$ & $1.2753(2)$ & $0.11+1(2)$ & $0.0288(T)$ \\
\hline$C(b 7)$ & $0.7138(2)$ & $1.2086(2)$ & $0.1625(2)$ & $0.0238(6)$ \\
\hline$C(b 8)$ & $0.6616(2)$ & $1.1266(2)$ & $0.1616(2)$ & $0.0259(6)$ \\
\hline $\mathrm{C}(\mathrm{m} 1)$ & $0.6941(2)$ & $0.9474(2)$ & $0.1478(2)$ & $0.0244(6)$ \\
\hline$C(\mathrm{~m} 3)$ & $1.1348(2)$ & $1.0404(2)$ & $0.0698(2)$ & $0.0281(6)$ \\
\hline$C(m-1)$ & $0.8795(2)$ & $1.2374(2)$ & $0.1+20(2)$ & $0.0240(6)$ \\
\hline$C(11)$ & $0.6234(2)$ & $0.7321(2)$ & $0.1+28(2)$ & $0.0296(7)$ \\
\hline$C(41)$ & $1.2663(2)$ & $0.8704(3)$ & $0.0390(2)$ & $0.0307(T)$ \\
\hline$C(51)$ & $1.2110(2)$ & $1.248 i(3)$ & $0.0832(3)$ & $0.0477(1)$ \\
\hline$C(61)$ & $1.0414(2)$ & $1.3825(2)$ & $0.1297(2)$ & $0.0344(\bar{T})$ \\
\hline$C(71)$ & $0.6838(2)$ & $1.3121(2)$ & $0.1734(2)$ & $0.0278(6)$ \\
\hline$C(81)$ & $0.5605(2)$ & $1.1201(2)$ & $0.1693(2)$ & $0.0339(7)$ \\
\hline$C(12)$ & $0.5743(3)$ & $0.7365(4)$ & $0.0662(2)$ & $0.0659(15)$ \\
\hline$C(42)$ & $1.3281(2)$ & $0.8813(3)$ & $0.1084(2)$ & $0.0321(7)$ \\
\hline$C(52)$ & $1.2709(2)$ & $1.2204(3)$ & $0.1517(3)$ & $0.0531(12)$ \\
\hline$C(62)$ & $1.0558(3)$ & $1.4051(3)$ & $0.2136(2)$ & $0.0464(9)$ \\
\hline$C(72)$ & $0.6431(2)$ & $1.3581(2)$ & $0.1019(2)$ & $0.0308(7)$ \\
\hline$C(82)$ & $0.5131(2)$ & $1.1026(3)$ & $0.0927(3)$ & $0.0473(10)$ \\
\hline$O(1)$ & $0.95926(13)$ & $0.99059(14)$ & $0.24373(11)$ & $0.0204(4)$ \\
\hline $\mathrm{O}(2)$ & $1.0345(2)$ & $0.8559(2)$ & $0.2800(2)$ & $0.0412(6)$ \\
\hline
\end{tabular}


(a) $\left[\mathrm{Fe}(\mathrm{OEP})\left(\mathrm{O}_{2} \mathrm{C}_{2} \mathrm{Cl}_{3}\right)\right]$. continued

\begin{tabular}{|c|c|c|c|c|}
\hline atom & $x$ & $y$ & $z$ & {$[(\mathrm{eq})$} \\
\hline$C(1)$ & $1.0245(2)$ & $0.9427(2)$ & $0.275+(2)$ & $0.0229(6)$ \\
\hline $\mathrm{C}(2)$ & $1.0992(2)$ & $1.0080(2)$ & $0.3128(2)$ & $0.0254(6)$ \\
\hline $\mathrm{Cl}(1)$ & $1.08767(5)$ & $1.13328(5)$ & $0.2914 \bar{i}(5)$ & $0.0323(2)$ \\
\hline $\mathrm{Cl}(2)$ & $1.20532(6)$ & $0.96876(\bar{i})$ & $0.27861(7)$ & $0.0518(3)$ \\
\hline Cli 3$)$ & $1.09563(9)$ & $0.99225(9)$ & $0.41259(.5)$ & $0.05-5(3)$ \\
\hline$C(a 2 a)$ & $0.8645(4)$ & $0.7872(4)$ & $0.1054(4)$ & $0.0204(12)$ \\
\hline$C(a 3 a)$ & $1.0250(3)$ & $0.8210(4)$ & $0.0791(3)$ & $0.0127(10)$ \\
\hline$C(b 2 a)$ & $0.7889(t)$ & $0.721 .5(4)$ & $0.1088(4)$ & $0.0249(13)$ \\
\hline$C(b 3 a)$ & $1.1149(3)$ & $0.7899(4)$ & $0.05 \pi(3)$ & $0.0131(10)$ \\
\hline $\mathrm{C}(\mathrm{m} 2 \mathrm{a})$ & $0.9517(t)$ & $0.7590(4)$ & $0.08 i \div(3)$ & $0.0195(12)$ \\
\hline$C(21 a)$ & $0.7908(5)$ & $0.6153(5)$ & $0.0854(4)$ & $0.036(2)$ \\
\hline$C(31 a)$ & $1.1421(4)$ & $0.6843(4)$ & $0.0+89(3)$ & $0.0215(12)$ \\
\hline$C(22 a)$ & $0.8181(6)$ & $0.5 .549(7)$ & $0.1518(5)$ & $0.048(2)$ \\
\hline$C(32 a)$ & $1.1579(5)$ & $0.6340(6)$ & $0.1274(5)$ & $0.037(2)$ \\
\hline$C(a 2 b)$ & $0.8733\left(\frac{1}{2}\right)$ & $0.7679(4)$ & $0.1318(4)$ & $0.0149(11)$ \\
\hline$C(a 3 b)$ & $1.03+1(4)$ & $0.8022(4)$ & $0.1066(4)$ & $0.0208(12)$ \\
\hline$C(b 2 b)$ & $0.7982(4)$ & $0.7031(4)$ & $0.1409(3)$ & $0.0145(11)$ \\
\hline$C(b 3 b)$ & $1.1256(4)$ & $0.7711(t)$ & $0.0895(4)$ & $0.0230(12)$ \\
\hline$C(m 2 b)$ & $0.9631(4)$ & $0.741+(4)$ & $0.1232(4)$ & $0.0202(12)$ \\
\hline$C(21 b)$ & $0.8047(4)$ & $0.5966(5)$ & $0.1435(3)$ & $0.0183(12)$ \\
\hline$C(31 b)$ & $1.1614(5)$ & $0.6663(5)$ & $0.0977(1)$ & $0.033(2)$ \\
\hline$C(22 b)$ & $0.8143(4)$ & $0.5464(4)$ & $0.0653(3)$ & $0.0219(13)$ \\
\hline$C(32 b)$ & $1.1377(5)$ & $0.6050(6)$ & $0.0316(4)$ & $0.041(2)$ \\
\hline
\end{tabular}

(b) $\left[\mathrm{Fe}(\mathrm{OEP})\left(\mathrm{O}_{2} \mathrm{C}_{2} \mathrm{Cl}_{3}\right)\right] \cdot \mathrm{CHCl}_{3}$

\begin{tabular}{llllr}
\hline atom & \multicolumn{1}{c}{$x$} & \multicolumn{1}{c}{$y$} & \multicolumn{1}{c}{$z$} & $U(\mathrm{eq})$ \\
\hline $\mathrm{Fe}$ & $0.50641(3)$ & $0.31284(2)$ & $0.42340(2)$ & $0.0093(1)$ \\
$\mathrm{N}(1)$ & $0.5962(2)$ & $0.47274(13)$ & $0.44995(13)$ & $0.0120(3)$ \\
$\mathrm{N}(2)$ & $0.3863(2)$ & $0.17376(13)$ & $0.43070(13)$ & $0.0111(3)$ \\
$\mathrm{N}(3)$ & $0.6255(2)$ & $0.29722(13)$ & $0.56757(13)$ & $0.0111(3)$ \\
$\mathrm{N}(1)$ & $0.3595(2)$ & $0.34759(14)$ & $0.31029(13)$ & $0.0126(3)$ \\
$\mathrm{C}(\mathrm{a} 1)$ & $0.2698(2)$ & $0.1258(2)$ & $0.3573(2)$ & $0.0121(4)$ \\
$\mathrm{C}(\mathrm{a} 2)$ & $0.4115(2)$ & $0.1015(2)$ & $0.5024(2)$ & $0.0118(4)$ \\
$\mathrm{C}(\mathrm{a} 3)$ & $0.6171(2)$ & $0.2095(2)$ & $0.62180(15)$ & $0.0112(4)$ \\
$\mathrm{C}(\mathrm{a} 4)$ & $0.7379(2)$ & $0.3676(2)$ & $0.62494(15)$ & $0.0126(4)$ \\
$\mathrm{C}(\mathrm{a} 5)$ & $0.7154(2)$ & $0.5190(2)$ & $0.5204(2)$ & $0.0131(4)$ \\
$\mathrm{C}(\mathrm{a} 6)$ & $0.5661(2)$ & $0.5489(2)$ & $0.3851(2)$ & $0.0135(4)$ \\
\hline
\end{tabular}


(b) $\left[\mathrm{Fe}(\mathrm{OEP})\left(\mathrm{O}_{2} \mathrm{C}_{2} \mathrm{Cl}_{3}\right)\right] \cdot \mathrm{CHCl}_{3}$, continued.

\begin{tabular}{|c|c|c|c|c|}
\hline atom & $x$ & $y$ & $z$ & C'eq) \\
\hline Cl(la) & $0.59522(14)$ & $0.20250(7)$ & $0.08 .5+3(9)$ & $0.037+(3)$ \\
\hline $\mathrm{Cl}(2 \mathrm{a})$ & $0.77077(9)$ & $0.346 .52(11)$ & $0.25940(\bar{\tau})$ & $0.0431(4)$ \\
\hline $\mathrm{Cl}(3 \mathrm{a})$ & $0.5+21(2)$ & $0.391 \pm 6(13)$ & $0.13683(13)$ & $0.0 .522(5)$ \\
\hline $\mathrm{Cl}(\mathrm{Bb})$ & $0.7+42(11)$ & $0.3882(10)$ & $0.25 \div 6(8)$ & $0.031(3)$ \\
\hline $\mathrm{Cl}(2 \mathrm{~b})$ & $0.6432(20)$ & $0.2125(15)$ & $0.116 \pm(16)$ & $0.0 .5 .5(5)$ \\
\hline $\mathrm{Cl}(3 \mathrm{~b})$ & $0.5060(9)$ & $0.3532(10)$ & $0.1033(8)$ & $0.026(2)$ \\
\hline$C(3)$ & $0.2618(3)$ & $0.0966(2)$ & $0.9883(2)$ & $0.0285(5)$ \\
\hline $\mathrm{Cl}(4)$ & $0.136 .50(8)$ & $0.01452(6)$ & $1: 00869(i)$ & $0.0430(2)$ \\
\hline $\mathrm{Cl}(5)$ & $0.29625(9)$ & $0.02795(6)$ & $0.90383(6)$ & $0.0420(2)$ \\
\hline $\mathrm{Cl}(6)$ & $0.225+12(13)$ & $0.21311(6)$ & $0.94052(9)$ & $0.0630(3)$ \\
\hline \multicolumn{5}{|c|}{ (c) $\left.\mathrm{Fe}(\mathrm{OEP})\left(\mathrm{O}_{2} \mathrm{C}_{2} \mathrm{Cl}_{3}\right)\right] \cdot \mathrm{HO}_{2} \mathrm{C}_{2} \mathrm{Cl}_{3}$} \\
\hline atom & $I$ & $y$ & $z$ & $i(e q)$ \\
\hline Fel_l & $-0.19632(\bar{i})$ & $1.05118(6)$ & $0.02825(3)$ & $0.028 .5(2)$ \\
\hline $\mathrm{Nl}-1$ & $-0.2719(4)$ & $0.9280(3)$ & $0.05623(19)$ & $0.0250(10)$ \\
\hline$\therefore 2.1$ & $-0.0816(4)$ & $1.0230(3)$ & $0.0833(2)$ & $0.0295(10)$ \\
\hline$\therefore 3$ & $-0.0956(4)$ & $1.1370(3)$ & $-0.01549(19)$ & $0.02 \pi 9(10)$ \\
\hline$N+1$ & $-0.2887(4)$ & $1.0437(3)$ & $-0.0411(2)$ & $0.0282(10)$ \\
\hline Cal_1 & $-0.3580(5)$ & $0.8788(4)$ & $0.0333(2)$ & $0.0304(12)$ \\
\hline $\mathrm{Ca2}-1$ & $-0.2561(5)$ & $0.8837(4)$ & $0.1077(2)$ & $0.0315(13)$ \\
\hline Ca3_l & $-0.0889(5)$ & $0.9641(4)$ & $0.1302(3)$ & $0.0318(13)$ \\
\hline $\mathrm{Cat}+1$ & $0.01 \div 3(5)$ & $1.0676(t)$ & $0.0868(2)$ & $0.0299(12)$ \\
\hline $\mathrm{Ca5} .1$ & $0.0012(5)$ & $1.1692(4)$ & $0.0012(2)$ & $0.0303(12)$ \\
\hline Ca6.1 & $-0.1185(1)$ & $1.1913(4)$ & $-0.0627(2)$ & $0.0292(12)$ \\
\hline Ca7.1 & $-0.2870(5)$ & $1.1111(4)$ & $-0.0850(2)$ & $0.0292(12)$ \\
\hline Ca8.1 & $-0.3745(4)$ & $0.9817(1)$ & $-0.0519(2)$ & $0.0270(12)$ \\
\hline Cbl_1 & $-0.3951(5)$ & $0.8034(4)$ & $0.0704(3)$ & $0.0317(13)$ \\
\hline $\mathrm{Cb} 2 \_1$ & $-0.3353(5)$ & $0.8080\left(\frac{1}{2}\right)$ & $0.1175(3)$ & $0.0333(13)$ \\
\hline Cb3_1 & $0.0045(5)$ & $0.9711(4)$ & $0.1640(2)$ & $0.0337(13)$ \\
\hline $\mathrm{Cb} 4 \_1$ & $0.0688(5)$ & $1.0373(4)$ & $0.1364(2)$ & $0.0330(13)$ \\
\hline Cb5.1 & $0.0407(4)$ & $1.2439(4)$ & $-0.0361(2)$ & $0.0303(12)$ \\
\hline Cb6.1 & $-0.0334(5)$ & $1.2575(4)$ & $-0.0764(3)$ & $0.0321(13)$ \\
\hline $\mathrm{Cb} 7.1$ & $-0.3754(5)$ & $1.0918(5)$ & $-0.1225(3)$ & $0.0326(13)$ \\
\hline Cb8_1 & $-0.4252(4)$ & $1.0100(5)$ & $-0.1029(3)$ & $0.0323(13)$ \\
\hline Cml_I & $-0.1723(5)$ & $0.9027(4)$ & $0.1424(2)$ & $0.0318(13)$ \\
\hline Cm2_1 & $0.0527(5)$ & $1.1353(4)$ & $0.0481(3)$ & $0.0328(13)$ \\
\hline
\end{tabular}


(c) $\left[\mathrm{Fe}(\mathrm{OEP})\left(\mathrm{O}_{2} \mathrm{C}_{2} \mathrm{Cl}_{3}\right)\right] \cdot \mathrm{HO}_{2} \mathrm{C}_{2} \mathrm{Cl}_{3}$. continued.

\begin{tabular}{|c|c|c|c|c|}
\hline atom & $I$ & $y$ & $z$ & $l^{\prime}(\mathrm{eq})$ \\
\hline $\mathrm{Cm} 3{ }_{1}$ & $-0.2091(5)$ & $1.1811(4)$ & $-0.0933(2)$ & $0.030 \pi(12)$ \\
\hline$C n: t_{-1}$ & $-0.4044(5)$ & $0.90+i(4)$ & $-0.0171(2)$ & $0.0343(13)$ \\
\hline C11.1 & $-0.4815(5)$ & $0.729 \div(5)$ & $0.0557(3)$ & $0.0408(1.5)$ \\
\hline$C .21 .1$ & $-0.3 \pm 31(5)$ & $0.7452(5)$ & $0.1688(3)$ & $0.0382(14)$ \\
\hline C 31.1 & $0.0236(5)$ & $0.9210(5)$ & $0.2182(3)$ & $0.0+22(1.5)$ \\
\hline$C+1.1$ & $0.1744(5)$ & $1.0737(5)$ & $0.1534(3)$ & $0.0362(14)$ \\
\hline C51_1 & $0.1425(5)$ & $1.2975(5)$ & $-0.0289(3)$ & $0.0383(1.5)$ \\
\hline C61_1 & $-0.0313(6)$ & $1.3276(5)$ & $-0.1243(3)$ & $0.0430(16)$ \\
\hline C71.1 & $-0.3977(5)$ & $1.1509(5)$ & $-0.17+0(3)$ & $0.0380(14)$ \\
\hline C81_i & $-0.5165(\overline{5})$ & $0.9550(5)$ & $-0.128+(3)$ & $0.0362(14)$ \\
\hline $\mathrm{C} 12.1$ & $-0.4464(6)$ & $0.6+32(5)$ & $0.0196(3)$ & $0.0480(17)$ \\
\hline C22.1 & $-0.2836(5)$ & $0.6513(5)$ & $0.1679(3)$ & $0.0+14(15)$ \\
\hline C 32.1 & $-0.0088(7)$ & $0.9799(6)$ & $0.2682(3)$ & $0.05 i(2)$ \\
\hline$C+2.1$ & $0.1775(5)$ & $1.1705(5)$ & $0.1865(3)$ & $0.0 \div 48(16)$ \\
\hline$C 52 \_1$ & $0.1416(6)$ & $1.3787(5)$ & $0.0168(3)$ & $0.0482(18)$ \\
\hline C62_1 & $-0.0582(8)$ & $1.4321(6)$ & $-0.1070(4)$ & $0.068(3)$ \\
\hline Ci2_L & $-0.3356(6)$ & $1.1270(5)$ & $-0.2253(3)$ & $0.0437(16)$ \\
\hline C82.1 & $-0.4884(6)$ & $0.8632(6)$ & $-0.1620(3)$ & $0.0505(18)$ \\
\hline Clla_l & $-0.3510(5)$ & $1.3548(3)$ & $0.0657(3)$ & $0.090(2)$ \\
\hline $\mathrm{Cl} 2 \mathrm{a}_{-} 1$ & $-0.2464(5)$ & $1.3873(3)$ & $0.16895(19)$ & $0.0842(19)$ \\
\hline $\mathrm{Cl3a}-1$ & $-0.1310(5)$ & $1.3588(3)$ & $0.0709(3)$ & $0.124(3)$ \\
\hline Cllb_l & $-0.3768(5)$ & $1.3613(5)$ & $0.1093(4)$ & $0.070(2)$ \\
\hline Cl2b_l & $-0.1690(7)$ & $1.4028(4)$ & $0.1372(4)$ & $0.089(4)$ \\
\hline Cl3b_1 & $-0.2288(7)$ & $1.3515(4)$ & $0.0246(3)$ & $0.089(3)$ \\
\hline $\mathrm{C} 2.1$ & $-0.2463(6)$ & $1.3260(5)$ & $0.1002(3)$ & $0.0482(18)$ \\
\hline $\mathrm{C} 1.1$ & $-0.2421(5)$ & $1.2112(4)$ & $0.1116(3)$ & $0.0320(13)$ \\
\hline O2.1 & $-0.2202(4)$ & $1.1858(t)$ & $0.15869(19)$ & $0.0488(12)$ \\
\hline O1_1 & $-0.2622(3)$ & $1.1597(3)$ & $0.06795(17)$ & $0.0331(9)$ \\
\hline ClSi_l & $-0.26772(19)$ & $-0.11029(14)$ & $0.31767(8)$ & $0.0625(6)$ \\
\hline $\mathrm{ClS} 2.1$ & $-0.32896(18)$ & $0.04586(16)$ & $0.39058(8)$ & $0.0617(5)$ \\
\hline ClS3_1 & $-0.45736(18)$ & $-0.01+7(2)$ & $0.29664(11)$ & $0.0926(10)$ \\
\hline CS2_1 & $-0.3307(5)$ & $0.0040(6)$ & $0.3211(3)$ & $0.0463(17)$ \\
\hline CS1_1 & $-0.2741(5)$ & $0.0781(5)$ & $0.2828(3)$ & $0.0374(14)$ \\
\hline OS1_1 & $-0.2824(4)$ & $0.0500(t)$ & $0.23011(19)$ & $0.0431(11)$ \\
\hline OS2_1 & $-0.2287(4)$ & $0.1513(4)$ & $0.3012(2)$ & $0.0549(14)$ \\
\hline
\end{tabular}


(c) $\left[\mathrm{Fe}(\mathrm{OEP})\left(\mathrm{O}_{2} \mathrm{C}_{2} \mathrm{Cl}_{3}\right)\right] \cdot \mathrm{HO}_{2} \mathrm{C}_{2} \mathrm{Cl}_{3}$. continued

\begin{tabular}{|c|c|c|c|c|}
\hline atom & $x$ & $y$ & $z$ & $\left.L^{* \prime} \in q\right)$ \\
\hline $\mathrm{Fel} 2 \mathrm{2}$ & $-0.19895(i)$ & $0.47076(6)$ & $0.53864(3)$ & 0.023612 \\
\hline$\therefore 12$ & $-0.2727(4)$ & $0.4780\left(\frac{1}{1}\right)$ & $0.4629(2)$ & $0.0309(11 ;$ \\
\hline$\therefore 22$ & $-0.2771(4)$ & $0.5906(3)$ & $0.56+8(2)$ & $0.0230120 ;$ \\
\hline$\therefore 3.2$ & $-0.097 \div(4)$ & $0.5006(3)$ & $0.6028(2)$ & $0.0301: 111$ \\
\hline$\therefore 4+2$ & $-0.0908(4)$ & $0.3916(3)$ & $0.5000(2)$ & $0.023+10 ;$ \\
\hline Cal_2 & $-0.2580(5)$ & $0.4190(5)$ & $0.4162(3)$ & $0.0373(14)$ \\
\hline $\mathrm{Ca} 222$ & $-0.35 i 6(5)$ & $0.5312(1)$ & $0.4 .500(2)$ & $0.0312: 131$ \\
\hline Ca3_2 & $-0.3601(4)$ & $0.6308(1)$ & $0.5380(2)$ & $0.0301(12)$ \\
\hline $\mathrm{Cat}_{2} 2$ & $-0.26+9(5)$ & $0.6413(4)$ & $0.6151(3)$ & $0.0321(13)$ \\
\hline $\mathrm{Ca} 52$ & $-0.1119(5)$ & $0.5576\left(\frac{1}{4}\right)$ & $0.6512(3)$ & $0.0323(13)$ \\
\hline $\mathrm{Ca}_{6} 2$ & $-0.0103(5)$ & $0.4499(4)$ & $0.6146(3)$ & $0.0316(13)$ \\
\hline $\mathrm{Ca} 7 \_2$ & $-0.0025(5)$ & $0.3575(4)$ & $0.5253(2)$ & $0.0310(13)$ \\
\hline $\mathrm{Car} 22$ & $-0.1008(5)$ & $0.3407(4)$ & $0.4494(2)$ & $0.0290(12)$ \\
\hline $\mathrm{Cbl} 2$ & $-0.3351(6)$ & $0.4368(5)$ & $0.3729(3)$ & $0.052(2)$ \\
\hline $\mathrm{Cb} 2 \_2$ & $-0.3973(5)$ & $0.50 .55(5)$ & $0.3945(3)$ & $0.0 \div 08(1.5)$ \\
\hline $\mathrm{Cb} 3{ }_{2} 2$ & $-0.3999(5)$ & $0.7092(5)$ & $0.5718(3)$ & $0.0361(14)$ \\
\hline $\mathrm{Cb} \div 2$ & $-0.3406(5)$ & $0.7156(5)$ & $0.6197(3)$ & $0.0363(14)$ \\
\hline $\mathrm{Cb} 52$ & $-0.0363(5)$ & $0.5408(1)$ & $0.6933(2)$ & $0.0320(13)$ \\
\hline Cb6 22 & $0.0276(5)$ & $0.1728(5)$ & $0.6712(3)$ & $0.0367(14)$ \\
\hline $\mathrm{Cb} 72$ & $0.0424(5)$ & $0.2854(4)$ & $0.4886(3)$ & $0.032 \pi(13)$ \\
\hline $\mathrm{Cb} 822$ & $-0.0197(5)$ & $0.2729(4)$ & $0.4+21(2)$ & $0.0296(12)$ \\
\hline Cm1_2 & $-0.3982(5)$ & $0.6012(1)$ & $0.4855(3)$ & $0.0328(13)$ \\
\hline $\mathrm{Cm} 2 \_2$ & $-0.1909(5)$ & $0.6236(4)$ & $0.6561(2)$ & $0.0311(13)$ \\
\hline $\mathrm{Cm} 32$ & $0.0348(5)$ & $0.3855(4)$ & $0.5778(2)$ & $0.0299(12)$ \\
\hline $\mathrm{Cm} 42$ & $-0.1802(5)$ & $0.3532(5)$ & $0.4111(3)$ & $0.0402(15)$ \\
\hline $\mathrm{Cl}_{1} 2$ & $-0.3286(8)$ & $0.3972(8)$ & $0.3125(4)$ & $0.039(3)$ \\
\hline $\mathrm{C} 11.2$ & $-0.3781(19)$ & $0.3556(17)$ & $0.3271(10)$ & $0.03 \div(6)$ \\
\hline $\mathrm{C} 212$ & $-0.4850(6)$ & $0.5529(5)$ & $0.3652(3)$ & $0.052(2)$ \\
\hline $\mathrm{C} 3122$ & $-0.4853(6)$ & $0.7732(6)$ & $0.5541(3)$ & $0.0483(18)$ \\
\hline $\mathrm{C}+12$ & $-0.3478(6)$ & $0.7883(5)$ & $0.6683(3)$ & $0.0465(17)$ \\
\hline $\mathrm{C} 5 \mathrm{C}_{2} 2$ & $-0.0297(5)$ & $0.5895(5)$ & $0.7503(3)$ & $0.0392(15)$ \\
\hline C61_2 & $0.1144(5)$ & $0.4241(.5)$ & $0.6989(3)$ & $0.0395(15)$ \\
\hline $\mathrm{CTI} 2$ & $0.1385(5)$ & $0.2325(5)$ & $0.5031(3)$ & $0.0391(15)$ \\
\hline
\end{tabular}




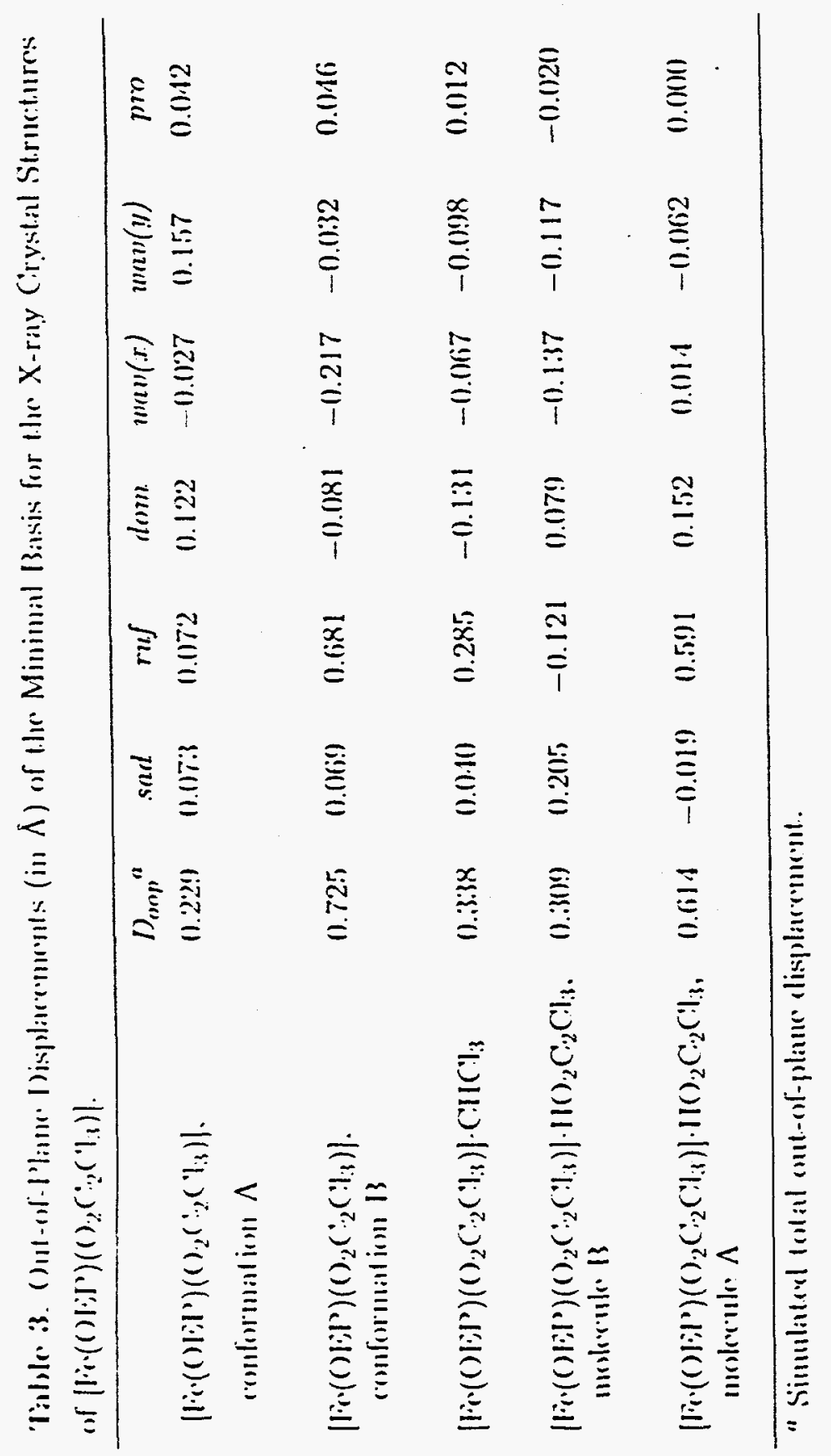




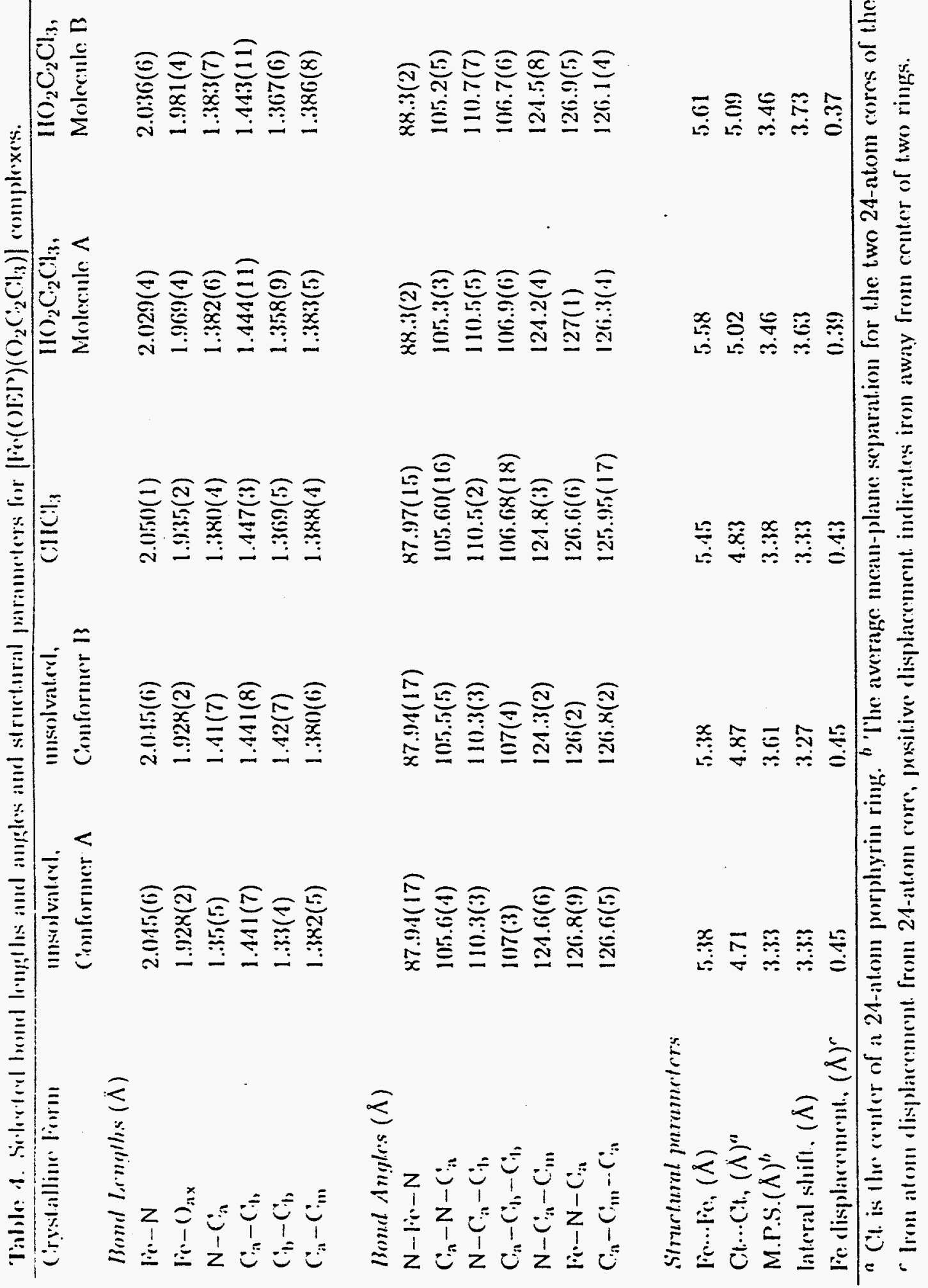


(b) $\left[\mathrm{Fe}(\mathrm{OEP})\left(\mathrm{O}_{2} \mathrm{C}_{2} \mathrm{Cl}_{3}\right)\right] \cdot \mathrm{CHCl}_{3}$. continued

\begin{tabular}{|c|c|c|c|c|}
\hline atom & $\Sigma$ & $y$ & $z$ & $C(e q)$ \\
\hline$C(a i)$ & $0.3599(2)$ & $0.4409(2)$ & $0.2638(2)$ & $0.0119(t)$ \\
\hline C $(a 3)$ & $0.2482(2)$ & $0.2758(2)$ & $0.2508(2)$ & $0.0132(t)$ \\
\hline$C(b 1)$ & $0.2202(2)$ & $0.0216(2)$ & $0.3831(2)$ & $0.0136(4)$ \\
\hline$C(b 2)$ & $0.30 \pi+(2)$ & $0.00 \pi 1(2)$ & $0.4 i \pm 0(2)$ & $0.0124(4)$ \\
\hline$C(b ; 3)$ & $0.7267(2)$ & $0.22 .58(2)$ & $0.71590(1.5)$ & $0.0139(4)$ \\
\hline$C^{\prime}(b+)$ & $0.3036(2)$ & $0.3233(2)$ & $0.7164(2)$ & $0.01+1+4)$ \\
\hline$C(b \cdot 5)$ & $0.7597(2)$ & $0.62 i 2(2)$ & $0.499+(2)$ & $0.01+9(4)$ \\
\hline $\mathrm{C}(\mathrm{b} 6)$ & $0.6671(2)$ & $0.6+56(2)$ & $0 .+155(2)$ & $0.0136(4)$ \\
\hline$C(b i)$ & $0.2492(2)$ & $0.4266(2)$ & $0.1722(2)$ & $0.01+1(4)$ \\
\hline$C(b 8)$ & $0.1785(2)$ & $0.3239(2)$ & $0.16 \div 1(2)$ & $0.0145(4)$ \\
\hline $\mathrm{C}(\mathrm{m} 1)$ & $0.2079(2)$ & $0.1719(2)$ & $0.2 \tau 23(2)$ & $0.0138(4)$ \\
\hline $\mathrm{C}(\mathrm{m} 2)$ & $0.5185(2)$ & $0.1179(2)$ & $0.5901(2)$ & $0.0125(4)$ \\
\hline$C(\mathrm{n} 23)$ & $0.7812(2)$ & $0.4696(2)$ & $0.6010(2)$ & $0.0138(4)$ \\
\hline$C(m+)$ & $0.45 .58(2)$ & $0.5347(2)$ & $0.3002(2)$ & $0.0139(4)$ \\
\hline$C(11)$ & $0.0946(2)$ & $-0.0522(2)$ & $0.3225(2)$ & $0.0182(t)$ \\
\hline$C(21)$ & $0.2994(2)$ & $-0.0837(2)$ & $0.5384(2)$ & $0.016 \pi(4)$ \\
\hline$C(31)$ & $0.7409(2)$ & $0.1510(2)$ & $0.7973(2)$ & $0.0175(4)$ \\
\hline$C(+1)$ & $0.9307(2)$ & $0.3778(2)$ & $0.79+3(2)$ & $0.0205(t)$ \\
\hline$C(51)$ & $0.8866(2)$ & $0.7000(2)$ & $0.5566(2)$ & $0.0213(5)$ \\
\hline$C(61)$ & $0.6670(2)$ & $0.7425(2)$ & $0.3585(2)$ & $0.0184(4)$ \\
\hline$C(i 1)$ & $0.2227(2)$ & $0.5091(2)$ & $0.0989(2)$ & $0.0187(4)$ \\
\hline$C(81)$ & $0.0529(2)$ & $0.2702(2)$ & $0.0844(2)$ & $0.0210(5)$ \\
\hline$C(12)$ & $-0.0052(2)$ & $-0.0291(2)$ & $0.3+89(2)$ & $0.0334(6)$ \\
\hline$C(22)$ & $0.2672(3)$ & $-0.0576(2)$ & $0.6267(2)$ & $0.0240(5)$ \\
\hline$C(32)$ & $0.6610(3)$ & $0.1572(2)$ & $0.8555(2)$ & $0.0247(5)$ \\
\hline$C(42)$ & $1.0308(2)$ & $0.3710(2)$ & $0.7596(2)$ & $0.0312(6)$ \\
\hline$C(52)$ & $0.9761(3)$ & $0.6879(3)$ & $0.5115(3)$ & $0.0422(8)$ \\
\hline$C(62)$ & $0.6870(3)$ & $0.728 \pm(2)$ & $0.2615(2)$ & $0.0261(5)$ \\
\hline$C(72)$ & $0.2953(3)$ & $0.5222(2)$ & $0.0315(2)$ & $0.0270(5)$ \\
\hline$C(82)$ & $-0.0497(2)$ & $0.27 .51(3)$ & $0.11 i 2(2)$ & $0.0364(7)$ \\
\hline$O(1)$ & $0.5875(2)$ & $0.27808(13)$ & $0.34196(12)$ & $0.0170(3)$ \\
\hline$C(1)$ & $0.5449(2)$ & $0.2296(2)$ & $0.2527(2)$ & $0.0181(4)$ \\
\hline$O(2)$ & $0.4608(2)$ & $0.1492(2)$ & $0.21+71(15)$ & $0.0310(t)$ \\
\hline$C(2)$ & $0.6125(2)$ & $0.2889(2)$ & $0.1861(2)$ & $0.0218(5)$ \\
\hline
\end{tabular}


(c) $\left[\mathrm{Fe}(\mathrm{OEP})\left(\mathrm{O}_{2} \mathrm{C}_{2} \mathrm{Cl}_{3}\right)\right] \cdot \mathrm{HO}_{2} \mathrm{C}_{2} \mathrm{Cl}_{3}$. continued.

\begin{tabular}{|c|c|c|c|c|}
\hline atom & $I$ & $y$ & $z$ & $L^{\prime}$ (eq) \\
\hline$C 81.2$ & $-0.0110(6)$ & $0.2010(5)$ & $0.39 .50(.3)$ & $0.0+27(16)$ \\
\hline $\mathrm{C} 12.2$ & $-0.4118(9)$ & $0.3125(9)$ & $0.30 .50(5)$ & $0.053\left(\frac{1}{2}\right)$ \\
\hline $\mathrm{C} 12: 2$ & $-0.3193(19)$ & $0.3929(18)$ & $0.27 \div 2(12)$ & $0.04 t(0)$ \\
\hline$C^{\prime} 22.2$ & $-0.4533(7)$ & $0.6522(6)$ & $0.338+(3)$ & $0.063(2)$ \\
\hline C 32.2 & $-0.4474(\vec{\imath})$ & $0.8 .589(6)$ & $0.5171(t)$ & $0.063(2)$ \\
\hline$C+2.2$ & $-0.272 t(6)$ & $0.8767(5)$ & $0.66+6(3)$ & $0.0529(19)$ \\
\hline C.52.2 & $0.0265(5)$ & $0.6920(5)$ & $0.7512(3)$ & $0.0424(16)$ \\
\hline C62_2 & $0.083 \vec{i}(6)$ & $0.3195 \%(5)$ & $0.7169(3)$ & $0.0510(18)$ \\
\hline$C 72 \_$ & $0.1204(6)$ & $0.1469(5)$ & $0.5+33(3)$ & $0.0 .502(18)$ \\
\hline C82.2 & $-0.0393(8)$ & $0.0949(6)$ & $0.4115(3)$ & $0.067(3)$ \\
\hline Cl1_2 & $-0.37596(14)$ & $0.13430(14)$ & $0.6113 \div(8)$ & $0.0514(5)$ \\
\hline $\mathrm{Cl} 2 \_2$ & $-0.2336(2)$ & $0.168+9(16)$ & $0.52341(10)$ & $0.0860(9)$ \\
\hline $\mathrm{Cl} 3 \_2$ & $-0.161 i t(19)$ & $0.13187(1 i)$ & $0.63575(14)$ & $0.0892(9)$ \\
\hline C2.2 & $-0.2555(5)$ & $0.1389(5)$ & $0.5944(3)$ & $0.042 \pi(16)$ \\
\hline $\mathrm{C} 1.2$ & $-0.25 i 8(5)$ & $0.3022(5)$ & $0.6116(3)$ & $0.0375(14)$ \\
\hline $\mathrm{O} 2.2$ & $-0.2439(5)$ & $0.3216(4)$ & $0.6610(2)$ & $0.0595(1.5)$ \\
\hline 012 & $-0.2 \pi T i(3)$ & $0.3581(3)$ & $0.57170(17)$ & $0.0349(10)$ \\
\hline $\mathrm{CIS} 12$ & $-0.3+27(2)$ & $0.4563(2)$ & $0.89179(9)$ & $0.0779(7)$ \\
\hline CIS2_2 & $-0.3118(2)$ & $0.61700(16)$ & $0.81697(12)$ & $0.08 .53(8)$ \\
\hline CIS32 & $-0.48858(19)$ & $0.4803(2)$ & $0.80350(12)$ & $0.0868(8)$ \\
\hline CS2_2 & $-0.3593(6)$ & $0.4939(5)$ & $0.8217(3)$ & $0.0523(19)$ \\
\hline $\mathrm{CS}_{1} 2$ & $-0.2979(6)$ & $0.42 \pi i(5)$ & $0.7817(3)$ & $0.0 \div 49(17)$ \\
\hline $\mathrm{OS}_{2} 2$ & $-0.3101(5)$ & $0.4550(4)$ & $0.7299(2)$ & $0.0571(14)$ \\
\hline OS2_2 & $-0.2184(6)$ & $0.3616(5)$ & $0.7988(2)$ & $0.0758(19)$ \\
\hline
\end{tabular}

${ }^{a} C(e q)$ is defined as one third of the trace of the orthogonalized $U_{1}$ tensor. The estimated standard deviations of the least significant digits are given in parentheses. 